Article

\title{
Analysis of Measurements of Direct Normal and Global Solar Radiation for Maceió, Alagoas State, Northeastern Brazil
}

\author{
José Marcelo Lopes Júnior ${ }^{1}$, José Leonaldo de Souza $^{1}$ (D), Ricardo Araujo Ferreira Junior ${ }^{1}$, \\ Cícero Manoel dos Santos ${ }^{2}$, Gustavo Bastos Lyra ${ }^{3}$, Chigueru Tiba ${ }^{4}$, \\ Rosiberto Salustiano da Silva Júnior ${ }^{1}$ \\ ${ }^{1}$ Setor de Agrometeorologia, Universidade Federal de Alagoas, Maceió, AL, Brasil. \\ ${ }^{2}$ Faculdade de Agronomia, Universidade Federal do Pará, Altamira, PA, Brasil. \\ ${ }^{3}$ Departamento de Ciências Ambientais, Universidade Federal Rural do Rio de Janeiro, \\ Seropédica, RJ, Brasil. \\ ${ }^{4}$ Departamento de Energia Nuclear, Universidade Federal de Pernambuco, Recife, PE, Brasil.
}

Received: 19 May 2019 - Accepted: 19 March 2020

\begin{abstract}
Studying solar radiation is essential for human knowledge, since it is present in practically all its activities. Thus, the aim of this work was to analyze the climatic and seasonal variation of direct normal and global solar radiation in the region of Maceió, Alagoas State, Northeastern Brazil with sky conditions characterized by clearness index $\left(K_{t}\right)$. The $K_{t}$ was determined by the ratio between global solar irradiance and solar irradiance at the top of the atmosphere. The highest occurrences of daily direct normal solar irradiance under conditions of $K_{t} \geq 0.6$ were recorded between $400 \mathrm{~W} \mathrm{~m}^{-2}$ and $700 \mathrm{~W} \mathrm{~m}^{-2}$ for all seasons. Under conditions of $0.4 \leq K_{t}<0.6$, the daily direct normal solar irradiance occurred between $200 \mathrm{~W} \mathrm{~m}^{-2}$ and $500 \mathrm{~W} \mathrm{~m}^{-2}$ and for conditions of $K_{t}<0.4$, its maximum value was $200 \mathrm{~W} \mathrm{~m}^{-2}$. It was observed that the levels of solar incidence in the study region depend on cloud cover conditions, with little influence of seasonality.
\end{abstract}

Keywords solar irradiance, climatic and seasonal analysis, sky conditions.

\section{Análise das Medidas de Radiação Solar Direta Normal e Global para Maceió, Estado de Alagoas, Nordeste do Brasil}

\begin{abstract}
Resumo
Estudar a radiação solar é essencial para o conhecimento humano, visto que ela está presente em praticamente todas suas atividades. Assim, o objetivo desse trabalho é analisar a variação climática e sazonal da radiação solar direta normal e global na região de Maceió, estado de Alagoas, Nordeste do Brasil com condições do céu caracterizada pelo índice de claridade $\left(K_{t}\right)$. O $K_{t}$ foi determinado pela razão entre irradiância solar global e irradiância solar no topo da atmosfera. As maiores ocorrências de irradiância solar direta normal diária em condições de $K_{t} \geq 0,6$ foram registradas entre $400 \mathrm{~W} \mathrm{~m}^{-2}$ e $700 \mathrm{~W} \mathrm{~m}^{-2}$ em todas as estações do ano. Sob condições de $0,4 \leq K_{t}<0,6$, a irradiância solar direta normal diária ocorreu entre $200 \mathrm{~W} \mathrm{~m}^{-2}$ e $500 \mathrm{~W} \mathrm{~m}^{-2}$ e para condições de $K_{t}<0,4$, seu valor máximo foi de $200 \mathrm{~W} \mathrm{~m}^{-2}$. Observou-se que os níveis de incidência solar na região de estudo dependem das condições de cobertura de nuvens, com pouca influência da sazonalidade.
\end{abstract}

Palavras-chave: irradiância solar, análise climática e sazonal, condição do céu.

\section{Introduction}

The radiation emitted by the Sun that arrives at Earth (top of the atmosphere and terrestrial surface) is the main source of energy that influences practically all human activities (Liou, 2002; Muneer, 2004; Santos et al., 2014). The knowledge of the global solar irradiance $\left(I_{G}\right)$ which is measured on a horizontal surface, direct normal solar irradiance $\left(I_{D}\right)$ and diffuse solar irradiance $\left(I_{d}\right)$ has great importance in several scientific and technological areas,

Autor de correspondência: José Leonaldo De Souza, jls@ccen.ufal.br. 
e.g. meteorology, climatology, energy generation, agrometeorology, and others (Vick et al., 2012; Tabari and Talaee, 2014; Evseev and Kudish, 2015; Ferreira Junior et al., 2015; Santos et al., 2016).

Thus, solar radiation studies require reliable and readily available data series for applications at the site of interest. The instrumentation to obtain $I_{G}$ and $I_{D}$ time series is given by the installation of a network of solar monitoring stations with radiometers and data acquisition system. The amount and spectral distribution of $I_{G}$ and $I_{D}$ depend on astronomical, atmospheric and local parameters such as: solar zenith angle, aerosol concentration and properties, amount of ozone, clouds, altitude of the site and surface albedo (Kaskaoutis and Kambezidis, 2009). $I_{D}$ is very sensitive to the optical depth of the aerosol and exhibits high frequency variation to the dynamic effects of clouds, showing greater spatial and temporal variability than $I_{G}$, making it difficult to characterize daily and seasonal variability of solar radiation and its components (Kotti et al., 2014).

The climatic characterization of the solar radiation requires a series of long-term measurements. However, the availability of solar databases, especially long time and continuous $I_{D}$ is scarce. With the availability of measurements, different researchers studied the climatic characteristics of solar irradiance, especially the work of Liu and Jordan (1960). In Beer Sheva - Israel, Evseev and Kudish (2015) analyzed solar irradiance from 1985 to 2013 and observed that the site has high frequency of clear sky days. In Seville - Spain, Moreno-Tejera et al. (2016) showed an analysis of solar irradiance variation, applying a statistical characterization in different time partitions.

Despite the importance and interest of the scientific and governmental community, the knowledge of solar irradiance components on the surface is still in its beginning in the Brazilian territory, mainly because it is a country of great territorial extent. In Brazil, there are few solarimetric stations that simultaneously perform high quality measurements of $I_{G}$ and $I_{D}$ components. Studies analyzing databases of solar components are not so often found in specialized literature; however global solar radiation for several sites in Northeastern Brazil (NEB) has been evaluated (Tiba, 2001). The seasonal variations of the diurnal evolution of solar irradiance components based on measurements collected on the surface of the city of São Paulo - Brazil (Oliveira et al., 2002). The global solar irradiation was evaluated in Maceió (NEB) (Souza et al., 2005), showing a lower monthly average daily value in July and higher in November, with dry season (OctoberFebruary) average hourly values $12.26 \%$ higher than values in the rainy season (April-August). Analyzes and comparisons of solar components were made for the city of São Paulo and rural area of Botucatu-SP (Codato et al., 2008), in which, although located in similar latitude and altitude, the seasonal evolution of the daily values indi- cates that São Paulo receives, during the days of open sky, 7.8\% less in August and 5.1\% less in June than Botucatu. An observational characterization of the diurnal and seasonal variation of the solar irradiance components for Rio de Janeiro has been Marques Filho et al. (2016).

The research site is located in the metropolitan region of Maceió, with sugarcane cultivation in the vicinity, bathed by the Atlantic Ocean and large lagoons; thus, the local atmosphere is polluted by particulates originating from industries, burning and local fires, and elevation of the water vapor concentration that attenuates $I_{G}$ and, mainly, $I_{D}$. These very small solid or liquid particles, called aerosols, are determinants of the spread of $I_{D}$. On the other hand, water vapor acts in the earth's atmosphere as an $I_{D}$ absorber. The combined action of aerosol concentration and water vapor content significantly affects the magnitude and variability of $I_{D}$, influencing the transparency level of the atmosphere. The importance of solar radiation characterization for the region where there is a growing demand for solarimetric information for solar energy, fundamental for establishing public policies in the area of renewable energy is also highlighted. Thus, this paper presents a climatic and seasonal analysis of the effects of sky cover on $I_{G}$ and $I_{D}$ values in the metropolitan region of Maceió between years of 2011 and 2014.

\section{Material and Methods}

\subsection{Study area}

The measurements used in this study were obtained from the solarimetric station located at the Federal University of Alagoas ( $9^{\circ} 33^{\prime} \mathrm{S} ; 35^{\circ} 46^{\prime} \mathrm{W}$ and $100 \mathrm{~m}$ a.s.l.), in Maceió, capital of the State of Alagoas, located in eastern NEB (Fig. 1). The microregion of Maceió is located on the coast, with variation of altitude between $(0$ and 20$) \mathrm{m}$ in the lower region (coastal plain), between (20 and 180) $\mathrm{m}$ on the slopes and coastal boards, reaching $300 \mathrm{~m}$ at the northern end of the municipality (Fig. 1). This variation can cause changes in air temperature and winds. The solarimetric station is installed at $15 \mathrm{~km}$ from the Atlantic Ocean, with herbaceous vegetation and Atlantic Rainforest and hot and humid climate.

Alagoas is subdivided into three geographic mesoregions (Coastal/Humid Zones, Hinterland and Interior) with different types of climate and further details are described in Santos et al. (2014), Santos et al. (2016) and Barros et al. (2012). The microregion of Maceió is part of mesoregions of Coastal/Humid Zones. This mesoregion have hot and humid climate, with annual rainfall varying from 600 to $3000 \mathrm{~mm}$, the rainy season is concentrated between autumn and winter (from May to August), with $55.2 \%$ of the annual rainfall and the dry period occurs between spring and summer (November to February) with only $12.5 \%$ of the total rainfall (Lima, 1991; Souza and 


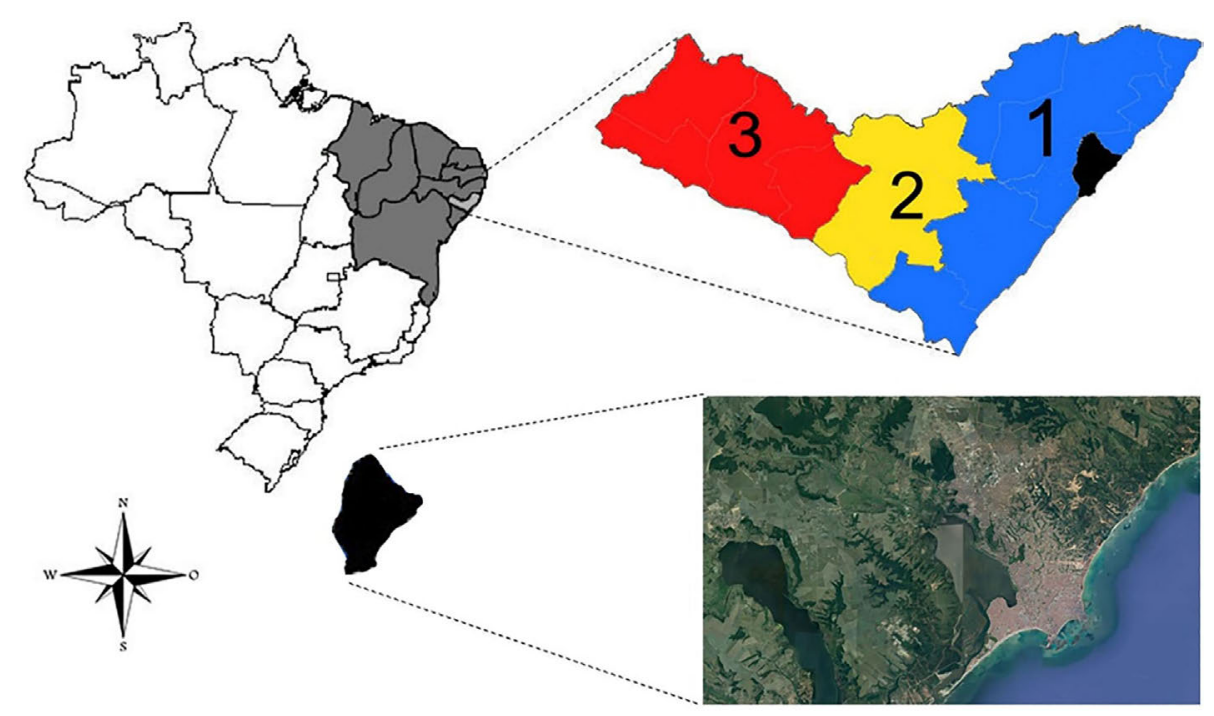

Figure 1 - Geographic location of northeastern Brazil (in dark gray), from the State of Alagoas with its mesoregions, Coastal/Humid Zones (1), Hinterland (2) and Interior (3) and municipality of Maceió (highlighted). Source: Google Maps, 2017.

Lima, 1995; Molion and Bernardo, 2002). The rainfall regime of the State of Alagoas is associated with several meteorological systems common to much NEB. Among the main systems, the coastal instability lines, seasonal variation of trade winds, position and intensity of the Intertropical Convergence Zone (ITCZ), Upper-Level Cyclonic Vortexes (ULCV), Eastern Waves (EW), are highlighted as the main ones (Souza et al., 2004; Lyra et al., 2014). In general, Alagoas has rainy season between May and July, when there is the maximum convergence of trade winds with the terrestrial breeze, which should be stronger during the autumn and winter seasons when the temperature contrast between land and sea is higher (Kousky, 1980), and a dry season between November and
January, a period in which a shift in the direction of trade winds takes place, which impairs the formation of clouds in the region.

\subsection{Obtaining data}

In this study measurements of global solar irradiance $\left(I_{G}\right)$ and direct normal solar irradiance $\left(I_{D}\right)$ were obtained from 2011 to 2014. Due to technical/operational problems, the $I_{D}$ database used is not continuous over the measurement period. The lack of electricity and non-linearization of the sensor with the solar disk are some factors responsible for significantly reducing the database. The $I_{G}$ component was measured with a piranometer model CM5 Kipp \& Zonen (Delft, The Netherlands) (Fig. 2). The $I_{D}$
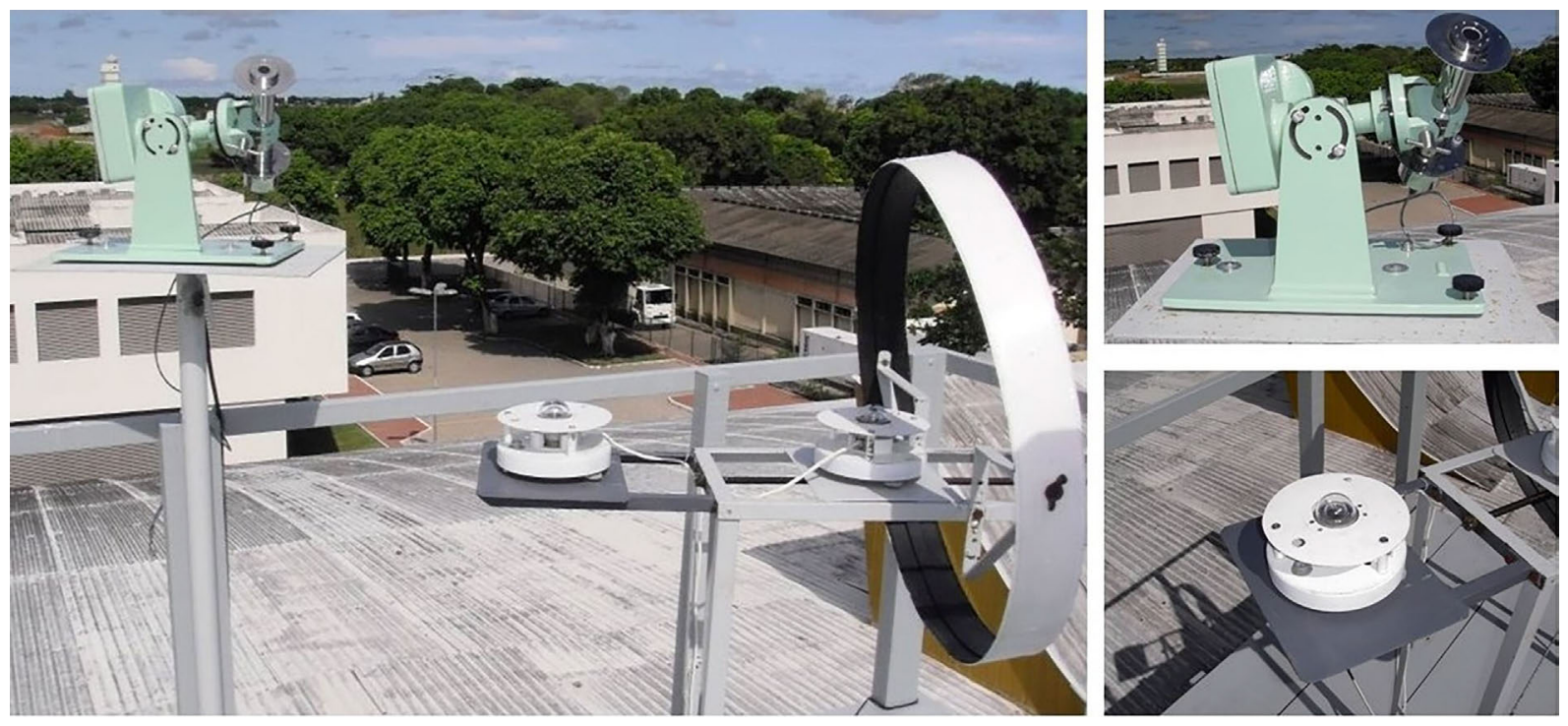

Figure 2 - Solarimetric station: Kipp \& Zonen CM5 pyranometer and pyrheliometer assembled on the Eppley solar tracker. 
component was measured by sNIP model secondary standard pyrheliometer assembled on an automatic solar tracker (Fig. 2) manufactured by Eppley. All sensors used followed the maintenance and calibration procedure according to manufacturer's recommendations (periodic calibration). Periodic checks throughout the measurements were made to ensure that the radiometer domes were clean, obtaining accurate and reliable measurements.

The radiometers used were connected to a Micrologger 21XL (Campbell Scientific Inc), with frequency of $1 \mathrm{~Hz}$ and programmed to take readings every $10 \mathrm{~s}$ and store the average every $10 \mathrm{~min}$. Hourly and daily data are calculated from the average values of $10 \mathrm{~min}$. The collected $I_{G}$ and $I_{D}$ data were integrated to produce global solar irradiation $\left(H_{G}\right)$ and direct normal solar irradiation $\left(H_{D}\right)$ on hourly $\left(H_{G}{ }^{h}\right.$ and $\left.H_{D}{ }^{h}\right)$ and daily $\left(H_{G}{ }^{d}\right.$ and $\left.H_{D}{ }^{d}\right)$ basis, respectively. A quality control process is essential before using any database of the place of interest. The quality of individual measures was verified according to recommendations of the World Meteorological Organization (WMO, 2008).

\subsection{Statistical and climatic analysis of measurements}

The measures of $I_{G}\left(H_{G}\right)$ and $I_{D}\left(H_{D}\right)$ in the hourly and daily time partitions were analyzed considering seasonality and local cloud cover. For statistical and climatic analysis of measurements, solar irradiance components were separated into periods and characterized in the different seasons of the year according to the region climatology, which is strongly dependent on the seasonality of precipitation and air temperature (Souza et al., 2004). In the Maceió region, the rainy season begins in April and ends in August, while the dry season begins in October and extends through February. Based on this seasonality and for further study, the climatic periods were separated into four: 1 - the dry (less rainy) period was separated into Dry Season (DS) (November to February); 2 - the transition period between dry and rainy season (March and April) was separated and defined as Pre-Rainy Season (PRS); 3 - the rainy season (May to August), will be called here as the Rainy Season (RS); 4 - the transition period between the rainy and dry season (September and October) was denominated as Pre-Dry Season (PDS).

The cloud cover was characterized from clearness index $\left(K_{t}\right)$ values in the hourly $\left(K_{\mathrm{t}}^{h}\right)$ and daily $\left(K_{t}^{d}\right)$ partitions, determined by the $K_{t}=I_{G} / I_{0}$ ratio. Thus, based on Iqbal (1983), some adaptations were made regarding $K_{t}$ intervals to the atmosphere of Maceió, when $\left(K_{t} \geq 0.60\right)$, the conditions are of Clear Sky (CS); when $\left(0.40 \leq K_{t}<\right.$ 0.60) characterizes Partially Cloudy Sky (PCS) condition and for $\left(K_{t}<0.40\right)$ it characterizes Overcast Sky (OS). For the representation of irradiance curves (irradiations) and estimates, days representing the different cloud cover conditions in each of the stations were randomly chosen. The $I_{G}$ and $I_{D}$ variations were elaborated with average mea- sures of $10 \mathrm{~min}$, and hourly curves of ${H_{G}}^{h}$ and $H_{D}{ }^{h}$ were plotted from the integration of the irradiance curves for each hour. Irradiance and irradiation analyses were performed between the interval between 06:00 am and 05:00 $\mathrm{pm}$, comprising practically the entire daytime period of solar incidence.

The average value of solar irradiance (global and direct) were separated into three different cloud cover conditions and four-time intervals. The average hourly of global solar irradiance $\left(\bar{I}_{G}^{h}\right)$ with the respective standard deviations $\left(\delta I_{G}^{h}\right)$ and the average hourly of direct normal solar irradiance $\left(\bar{I}_{D}^{h}\right)$ with the respective standard deviations $\left(\delta I_{D}^{h}\right)$ were calculated at each time interval. Histograms of direct normal daily solar irradiance $\left(I_{D}{ }^{d}\right)$ frequencies of each season of the year under study and under different cloud cover conditions were performed with the purpose of analyzing seasonal tendencies.

\subsection{Calculation of solar irradiance at the top of the atmosphere}

The solar irradiance at the top of the atmosphere $\left(I_{0}\right)$ was calculated by Eq. (1):

$$
I_{0}=I_{S C} E_{0} \cos \theta_{Z}
$$

in which $I_{S C}$ is the solar constant $\left(1367 \mathrm{~W} \mathrm{~m}^{-2}\right), E_{0}$ is the correction factor of the eccentricity of the, further details are described in Souza et al. (2005) and Iqbal (1983). $I_{0}$ data were integrated to obtain the solar irradiation values at the top of the atmosphere $\left(H_{0}\right)$, hourly $\left(H_{0}{ }^{h}\right)$ and daily $\left(H_{0}{ }^{d}\right)$.

\section{Results and Discussion}

\subsection{Climate and Weather system}

The climate of Maceió is "As" type, characterized as rainy tropical, with rain in the winter and autumn and dry in the summer (Köppen classification). The air temperature is high $\left(>20.0^{\circ} \mathrm{C}\right)$, with monthly thermal amplitude equal to $2.9^{\circ} \mathrm{C}$, average air temperature of $23.9^{\circ} \mathrm{C}$ in the coldest month (July) and $26.6^{\circ} \mathrm{C}$ in the hottest (March), the average is $25.4^{\circ} \mathrm{C}$ (Fig. 3a). In spring and summer, it is common to have days with maximum air temperature above $30.0{ }^{\circ} \mathrm{C}$, whereas in autumn and winter, daily air temperatures rarely reduce values below $20.0{ }^{\circ} \mathrm{C}$. The relative air humidity presents low annual fluctuation, with monthly average values greater than $75 \%$ (Fig. 3a), which is due to its proximity to the Atlantic Ocean. Rainfall in the wettest month is $341.9 \mathrm{~mm}$ (June) and in the least rainy month $30.2 \mathrm{~mm}$ (December); summer precipitation is approximately $293.4 \mathrm{~mm}$ (Fig. 3b). Spring is the season with the lowest precipitation $(168.8 \mathrm{~mm})$.

From November to March, precipitation is usually attributed to the convergence between the land breeze and 

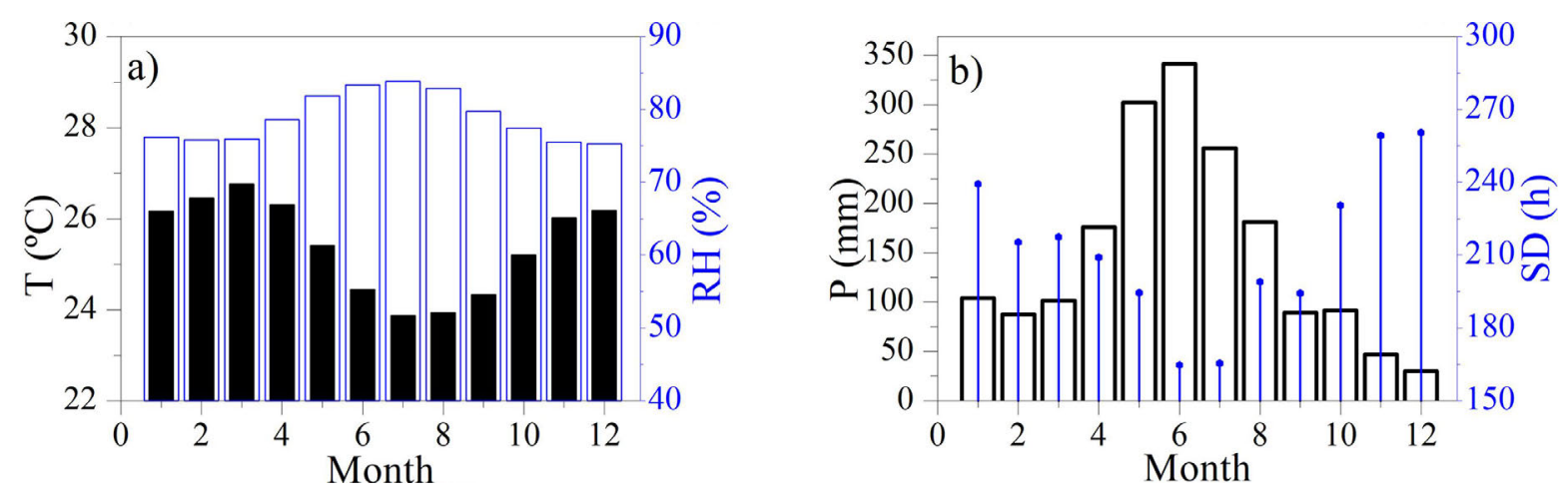

Figura 3 - Monthly average variation: a) Air temperature $\left(\mathrm{T},{ }^{\circ} \mathrm{C}\right)$ and Relative humidity $(\mathrm{RH}, \%)$; b) Precipitation $(\mathrm{P}, \mathrm{mm})$ and sunshine duration $(\mathrm{SD}$, hours). Data from 1995 to 2014 obtained from the National Institute of Meteorology (INMET).

the southeastern trade winds; however, in this time of year, this does not occur often, since a shift in the direction of trade winds decreases the intensity of the encounter with the terrestrial breeze, with lower contrast between the surface and the ocean temperatures. Another meteorological phenomenon contributing to the precipitation during this time of year is the ULCV, characterized as closed cyclone circulation with subsiding air in the center, and in these systems, the center has Clear Sky; however, its peripheries are submitted to large amounts of precipitation (Molion and Bernardo, 2002; Reboita et al., 2012). The precipitation reaches $820.2 \mathrm{~mm}$ and $527.2 \mathrm{~mm}$ in the autumn and winter, respectively. In the rainy season (April to August) precipitation is caused due to the action of some weather systems dependent on the effect of some surface and atmosphere configurations. We can highlight the occurrence of the penetration of frontal systems that may in some cases reach equatorial latitudes (Kousky, 1979), the convergence of trade winds with the terrestrial breeze that reaches its peak during the autumn and winter seasons with the increasing contrast of temperature between earth and ocean (Kousky, 1980), the eastern undulating disturbances known as eastern waves (EW) (Chou, 1990; Espinoza, 1996), and finally the action of the South Atlantic Convergence Zone (SACZ) when moved to lower latitudes (near Equator). The SACZ configuration is related to the ITCZ positioning, causing good part of the precipitation in Maceió (Molion and Bernardo, 2000). The month of December has the longest sunshine duration (SD) (260.4 hours), followed by November (259.2 hours) (Fig. 3b). The months of June (164.7 hours) and July (165.4 hours) are those with the lowest SD.

In addition to its proximity to the Atlantic Ocean, Maceió is also influenced by the presence of two large lagoons: Mundaú and Manguaba. The Mundaú lagoon has an approximate reservoir of $23 \mathrm{~km}^{2}$ and Manguaba with $42 \mathrm{~km}^{2}$. Both are located within a radius of $15 \mathrm{~km}$ south of Maceió. Their dimensions represent a local microclimate, causing interference in the atmosphere and in the microphysics of clouds. With the convection of the ocean and lagoons, the region of Maceió is strongly influenced by water vapor for most of the year (Fig. 4), helping in the formation and predominance of cumulus clouds in the local atmosphere. Water vapor accompanies the annual trend of air temperature and SD, increasing values in spring - summer and decreasing in autumn - winter.

\subsection{Analysis of solar irradiance under clear sky conditions (CS)}

Regardless of astronomical effect, on days whose sky has high atmospheric transmittance, the daytime solar irradiance variation is attributed only to atmospheric constituents (aerosols and water vapor, for example), mainly in the $I_{D}$ magnitude (Gueymard, 2012). Aerosols can reach levels that attenuate $I_{D}$ by approximately $70 \%$, or more in extreme conditions (Ruiz-Arias et al., 2016). Under CS, the daytime radiation components did not have large oscillations for DS, with total: $H_{G}{ }^{d}=27.52 \mathrm{MJ} \mathrm{m}^{-2}$ and $H_{D}{ }^{d}=31.33 \mathrm{MJ} \mathrm{m}^{-2}$, morning values $\left(H_{G}=16.34 \mathrm{MJ}\right.$ $\mathrm{m}^{-2}$ and $\left.H_{D}=18.41 \mathrm{MJ} \mathrm{m}^{-2}\right)$ and afternoon values $\left(H_{G}=11.18 \mathrm{MJ} \mathrm{m}^{-2}\right.$ and $H_{D}=12.92 \mathrm{MJ} \mathrm{m}^{-2}$ ) (Fig. 5a).

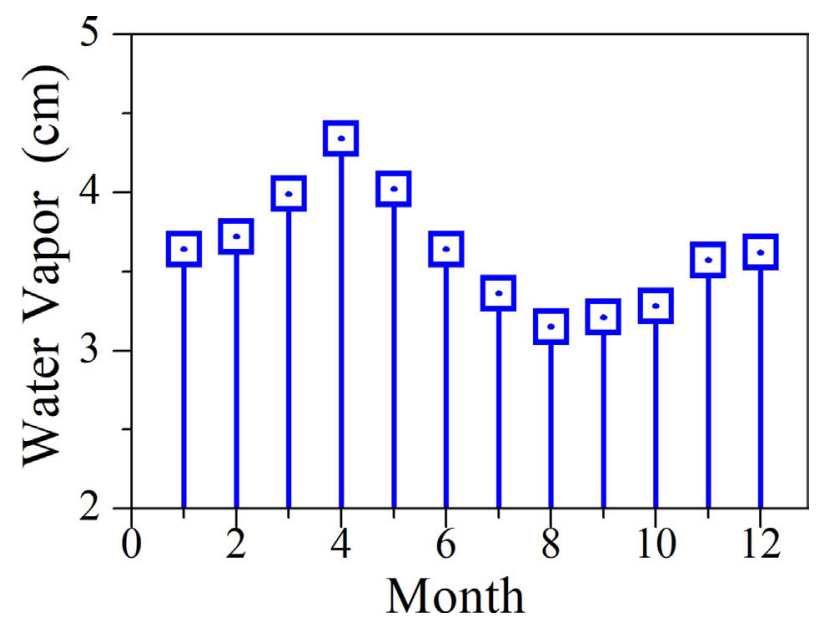

Figura 4 - Monthly average of water vapor in the atmosphere of Maceió. Source: Soda-pro. 
$H_{D}$ values in the morning (from sunrise to noon) and afternoon (from noon to sunset) are higher than $H_{G}$ values for the same period. This can be caused by the atmospheric optical mass and the method of measuring the solar components that are different. While $I_{D}\left(H_{D}\right)$ is measured directly (with the pyrheliometer) pointed at the solar disk (following diurnal solar trajectory), $I_{G}\left(H_{G}\right)$ is measured with fixed sensor (pyranometer) on the horizontal surface. The daily average $I_{G}$ and $I_{D}$ were $(687.2 \pm$ $\left.292.0 \mathrm{~W} \mathrm{~m}^{-2}\right)$ and $\left(787.0 \pm 148.6 \mathrm{~W} \mathrm{~m}^{-2}\right)$, respectively. The maximum $I_{G}$ value is close to that observed in Maceió (Porfírio et al., 2012) and higher than that found by Podstawczynska (2010). For six climatic zones in Nigeria and considering all types of sky cover condition, Chukwujindu and Julie (2017) found average values ranging from 6.30 to $28.8 \mathrm{MJm}^{-2}$.

In PRS, under CS conditions, daytime variation has a marked fluctuation caused by the passage of dispersed clouds in the atmosphere (Fig. $5 \mathrm{~b}$ ): with daily totals for $H_{G}{ }^{d}=26.99 \mathrm{MJ} \mathrm{m}^{-2}$ and $H_{D}{ }^{d}=28.07 \mathrm{MJ} \mathrm{m}^{-2}$. Although it is characterized as clear sky day, the daily formation of transient clouds of the cumulus type is common at this time of year due to the proximity of the region to the
Atlantic Ocean, which in some cases may develop into other types of clouds, both of horizontal or vertical development. The maximum $I_{G}$ and $I_{D}$ values were $1107.0 \mathrm{~W} \mathrm{~m}^{-2}$ and $905.8 \mathrm{~W} \mathrm{~m}^{-2}$, respectively. The daily average was $I_{G}=672.1 \pm 329.5 \mathrm{~W} \mathrm{~m}^{-2}$ and $I_{D}=702.4 \pm$ $183.6 \mathrm{~W} \mathrm{~m}^{-2}$. During this period of year, negative variation may occur due to the decrease of the solar radiation available at the top of the atmosphere and the increase of the water vapor content in the atmosphere, which is absorbed with greater intensity. Similar values for $I_{G}$ and $I_{D}$ irradiance was found for different sites in Portugal (Cavaco et al., 2016).

Also under CS conditions, for RS, the existence of greater oscillations and reduction of diurnal $I_{G}$ and $I_{D}$ values can be observed (Fig. 5c): with daily totals equal $20.90 \mathrm{MJ} \mathrm{m}^{-2}$ to $H_{G}$ and $24.02 \mathrm{MJ} \mathrm{m}^{-2}$ to $H_{D}{ }^{d}$ The maximum $I_{G}$ and $I_{D}$ values were $870.3 \mathrm{~W} \mathrm{~m}^{-2}$ and $824.0 \mathrm{~W}$ $\mathrm{m}^{-2}$, with daily average of $529.8 \pm 279.4 \mathrm{~W} \mathrm{~m}^{-2}$ and 632.0 $\pm 224.7 \mathrm{~W} \mathrm{~m}^{-2}$, respectively. During this period, there is a decrease in the available solar radiation due to the greater solar declination in the Northern Hemisphere, increase in cloudiness and reduction in the water vapor content in the local atmosphere. In addition, it is also verified that

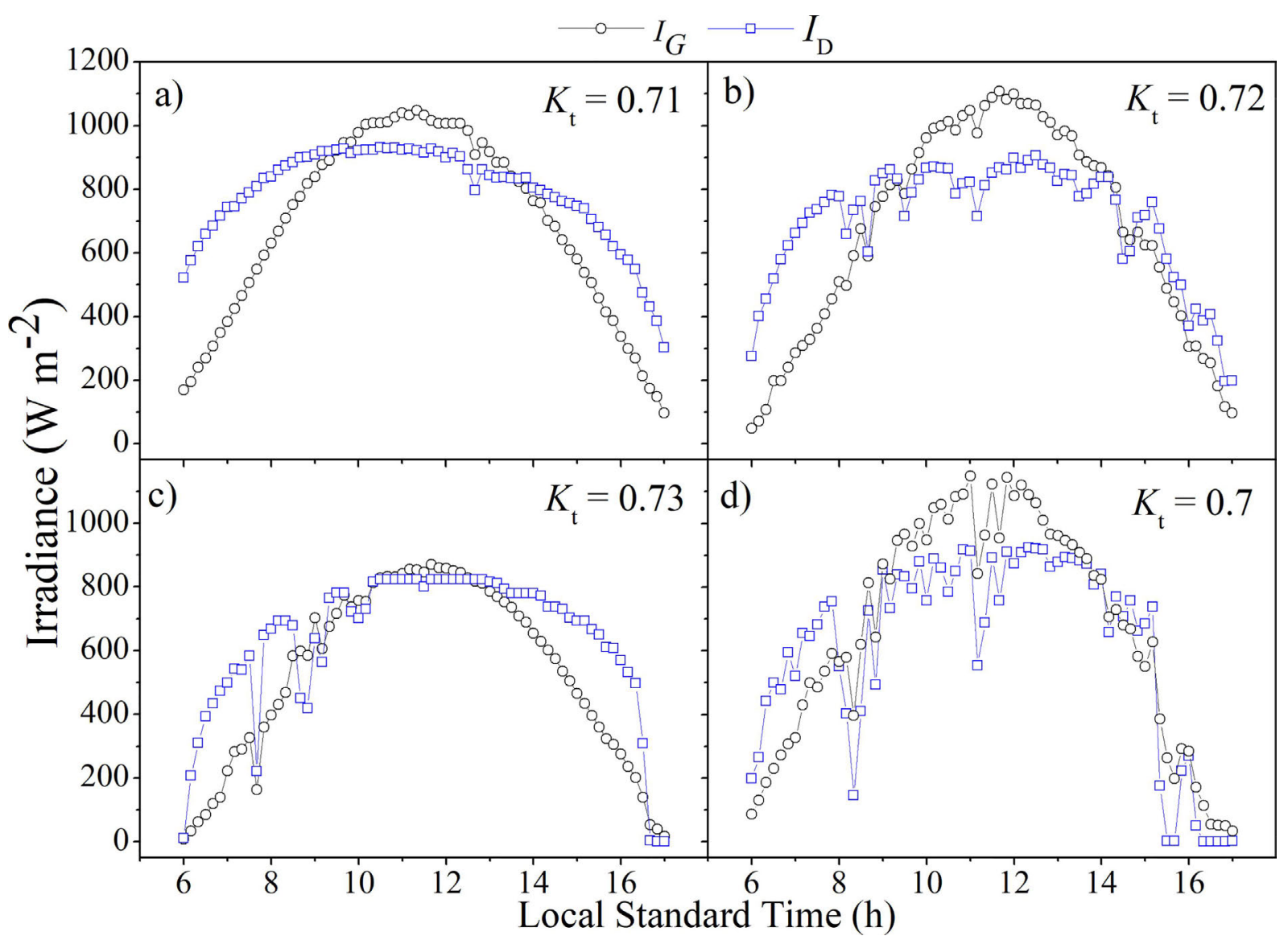

Figura 5 - Variation of global $\left(I_{G}\right)$ and direct normal $\left(I_{D}\right)$ solar irradiances under clear sky condition: (a) (12/12/2013) in dry season; (b) $(03 / 17 / 2011)$ in pre-rainy season; (c) (06/24/2011) in rainy season; (d) (10/09/2012) in pre-dry season. 
between 10:00 am and 01:00 pm, irradiance values are approximately constant, varying from (812.6 to 870.3 $\mathrm{W} \mathrm{m}{ }^{-2}$ ) for $I_{G}$ and from $\left(815.2\right.$ to $816.3 \mathrm{~W} \mathrm{~m}^{-2}$ ) for $I_{D}$.

Greater variations in values occurred in PDS during the daytime period, in which a sharp drop in the irradiance values was observed when $I_{G}$ decreased from (627.3 to $\left.385.1 \mathrm{~W} \mathrm{~m}^{-2}\right)$, and $I_{D}$ from $\left(738.6\right.$ to $175.4 \mathrm{~W} \mathrm{~m}^{-2}$ ) (Fig. 5d). This oscillation is the result of the dynamics of cumulus clouds in the local atmosphere, because in this period (PDS), the water vapor in the atmosphere remains approximately constant. The maximum values observed for the day were $I_{G}=1149.1 \mathrm{~W} \mathrm{~m}^{-2}$ and $I_{D}=923.2$ $\mathrm{W} \mathrm{m}{ }^{-2}$, with daily totals $H_{G}{ }^{d}=26.50 \mathrm{MJ} \mathrm{m}^{-2}$ and $H_{D}{ }^{d}=$ $24.52 \mathrm{MJ} \mathrm{m}^{-2}$. It was observed that $I_{D}$ increases with the elevation of $I_{G}$, revealing that $I_{D}$ is controlled by the variation of $I_{G}$. Results similar to those from Maceió for $I_{D}$ were obtained by Padova (northern Italy) and Trisaia (Southern Italy) (Dugaria et al., 2015).

\subsection{Analysis of solar irradiance under partially cloudy sky conditions (PCS)}

Under PCS condition, the irradiance curves have larger fluctuations throughout the day, caused mainly by the dynamics of cumulus clouds in the atmosphere (Fig. 6a-d). The maximum peaks $I_{G}$ and $I_{D}$ values were higher under PCS condition than on CS days. This is explained by the multi-reflections between the surface and the cloud bases, being phenomena typical of partially cloudy days, causing an increase of the descending reflection that increases the irradiance in comparison with cloud-free days (Porfírio et al., 2012). Souza et al. (2005) in a study on the solar irradiance for Maceió observed the occurrence of multiple reflections, confirmed by $I_{G}$ values very close to $I_{0}$. In different places in the State of Alagoas / Brazil, it has been reported that this phenomenon is not uncommon and occurs on at least one third of the days in a given month (Andrade and Tiba, 2016).

As expected, the $H_{G}{ }^{d}\left(20.52 \mathrm{MJ} \mathrm{m}^{-2}\right)$ and $H_{D}{ }^{d}$ values $\left(18.19 \mathrm{MJ} \mathrm{m}^{-2}\right)$ under PCS condition for DS were lower than those obtained under CS condition (Fig. 6a). The maximum $I_{G}$ and $I_{D}$ values were $1123.0 \mathrm{~W} \mathrm{~m}^{-2}$ and $929.8 \mathrm{~W} \mathrm{~m}^{-2}$, respectively, with average daily of $I_{G}=$ $512.2 \pm 292.6 \mathrm{~W} \mathrm{~m}^{-2}$ and $I_{D}=458.3 \pm 314.3 \mathrm{~W} \mathrm{~m}^{-2}$. The $H_{G}{ }^{d}$ values under these conditions were close to those observed by Porfírio et al. (2012). In the PRS, the irradiance that reached the surface was lower than in PDS, with daily average $I_{G}$ and $I_{D}$ values (maximum) of $507.6 \pm$ $278.3 \mathrm{~W} \mathrm{~m}^{-2}\left(1099.6 \mathrm{~W} \mathrm{~m}^{-2}\right)$ and $306.4 \pm 241.6 \mathrm{~W} \mathrm{~m}^{-2}$ $\left(859.0 \mathrm{~W} \mathrm{~m}^{-2}\right)$, respectively (Fig. 6b). The irradiation values were 20.05 and $11.58 \mathrm{MJ} \mathrm{m}^{-2}$ for $H_{G}{ }^{d}$ and $H_{D}{ }^{d}$, respectively. Similar values were observed by Polo et al. (2017).

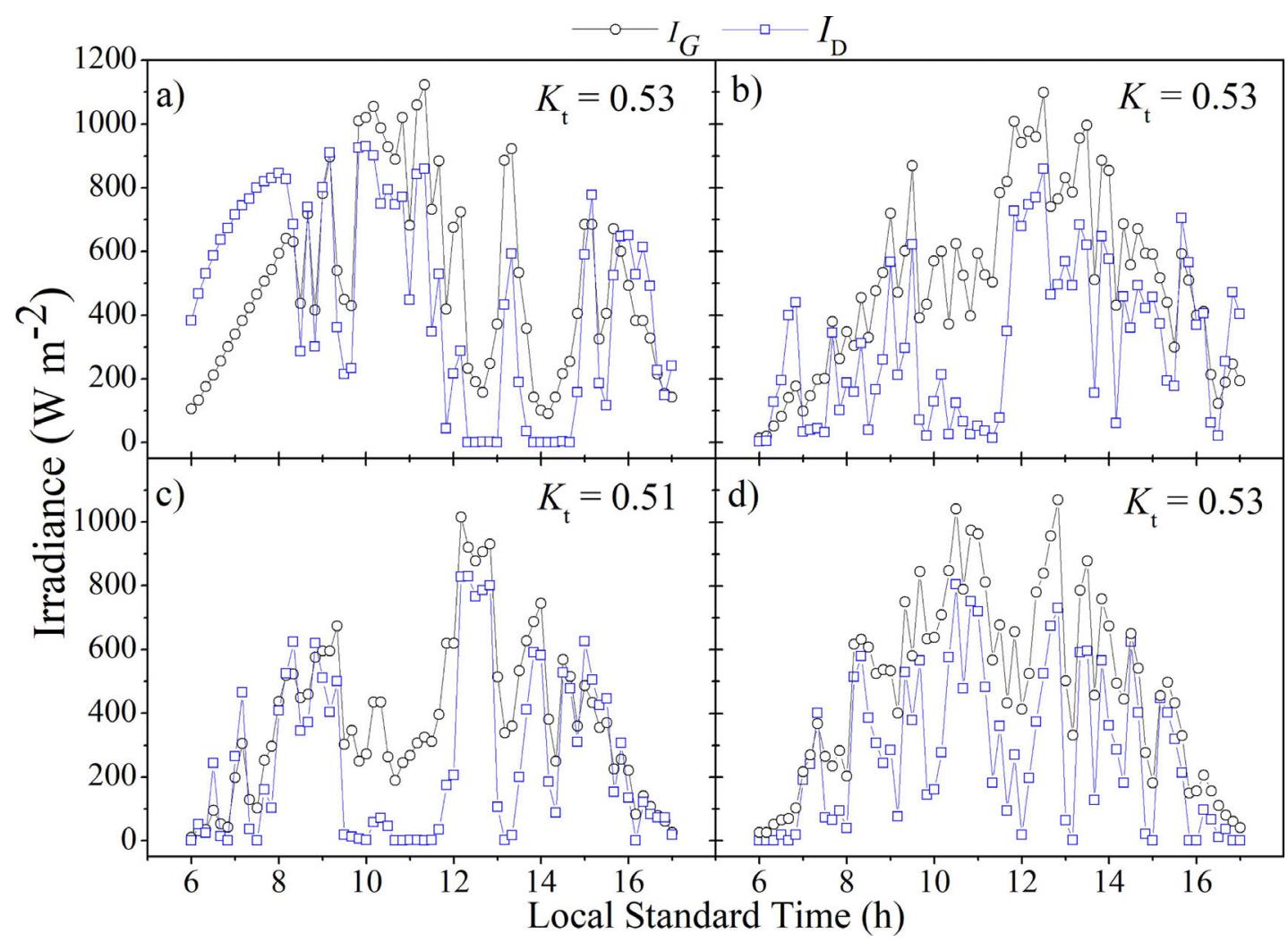

Figura 6 - Variation of global $\left(I_{G}\right)$ and direct normal $\left(I_{D}\right)$ solar irradiances under partially cloudy sky condition: (a) in dry season (01/09/2014), (b) in prerainy season (03/02/2013), (c) in rainy season (06/07/2012) and (d) in pre-dry season (09/17/2012). 
The solar irradiance values in RS were smaller when compared to the other seasons, with a sharp decrease (between 09:00 am and 12:00 am) in $I_{G}$ from (673.7 to $302.2 \mathrm{~W} \mathrm{~m}^{-2}$ ), while $I_{D}$ decreases from (500.7 to $18.8 \mathrm{~W} \mathrm{~m}^{-2}$ ) (Fig. 6c). The irradiance remained low and increased to the maximum peak of $I_{G}\left(1015.5 \mathrm{~W} \mathrm{~m}^{-2}\right)$ and $I_{D}\left(827.5 \mathrm{~W} \mathrm{~m}^{-2}\right)$. The average daily irradiance values were $I_{G}=378.2 \pm 244.5 \mathrm{~W} \mathrm{~m}^{-2}$ and $I_{D}=250.24 \pm$ $257.60 \mathrm{~W} \mathrm{~m}^{-2}$. During this period, cloudiness is the main responsible for the irradiance variations throughout the day. Irradiation values were $14.62 \mathrm{MJ} \mathrm{m}^{-2}$ and 9.49 MJ $\mathrm{m}^{-2}$ for $H_{G}{ }^{d}$ and $H_{D}{ }^{d}$, respectively. The average PRS values $\left[I_{G}=480.5 \pm 288.0 \mathrm{~W} \mathrm{~m}^{-2}\left(H_{G}{ }^{d}=19.29 \mathrm{MJ} \mathrm{m}^{-2}\right)\right.$ and $\left.I_{D}=272.2 \pm 238.2 \mathrm{~W} \mathrm{~m}^{-2}\left(H_{D}{ }^{d}=10.94 \mathrm{MJ} \mathrm{m}^{-2}\right)\right]$ are higher than those observed in RS and smaller than those observed in PRS and DS (Fig. 6d). In four sites in Australia, Grantham et al. (2017) found diurnal curves for $I_{G}$ and $I_{D}$ under CS and OS conditions with the same behavior of results of this research. On day of OS, evidences of the transient effects of clouds causing fluctuations in $I_{D}$ are observed. On day of CS, $I_{G}$ and $I_{D}$ do not exceed the value of $1000 \mathrm{~W} \mathrm{~m}^{-2}$. In Maceió, values above this value are observed.

\subsection{Analysis of solar irradiance under overcast sky conditions (OS)}

Under OS condition, low $I_{G}$ and $I_{D}$ values are expected, since much of the solar irradiance cannot cross the Earth's atmosphere, being absorbed, reflected or scattered by clouds. In this condition, the clouds result in a reduction in $I_{D}$ values. Therefore, the absence of clouds causes the elevation of $I_{G}$ and $I_{D}$ in CS days, while in OS days, $I_{D}$ tends to zero and the $I_{G}$ is significantly reduced to smaller values $\left(I_{G} \approx I_{d}\right)$. Thus, under OS condition, the daily $I_{G}$ values are greater than the daily $I_{D}$ values. Studies have shown that $I_{D}$ is much more sensitive than $I_{G}$ for changes in the amounts of clouds and aerosols (Ruiz-Arias et al., 2016). Moreover, in this sky cover, it is expected that the irradiance values for $\mathrm{DS}\left[I_{G}=362.4 \pm 161.3 \mathrm{~W} \mathrm{~m}^{-2}\right.$ and $\left.I_{D}=123.7 \pm 188.2 \mathrm{~W} \mathrm{~m}^{-2}\right]$ are lower than those observed in the other conditions (Fig. 7a). Peak $I_{G}$ and $I_{D}$ values were $732.7 \mathrm{~W} \mathrm{~m}^{-2}$ and $625.3 \mathrm{~W} \mathrm{~m}^{-2}$, respectively. It was observed that the morning, evening and daily $H_{G}$ totals were one of the lowest values found, especially during the morning, whose $I_{D}$ was almost non-existent, caused by cloud attenuation.

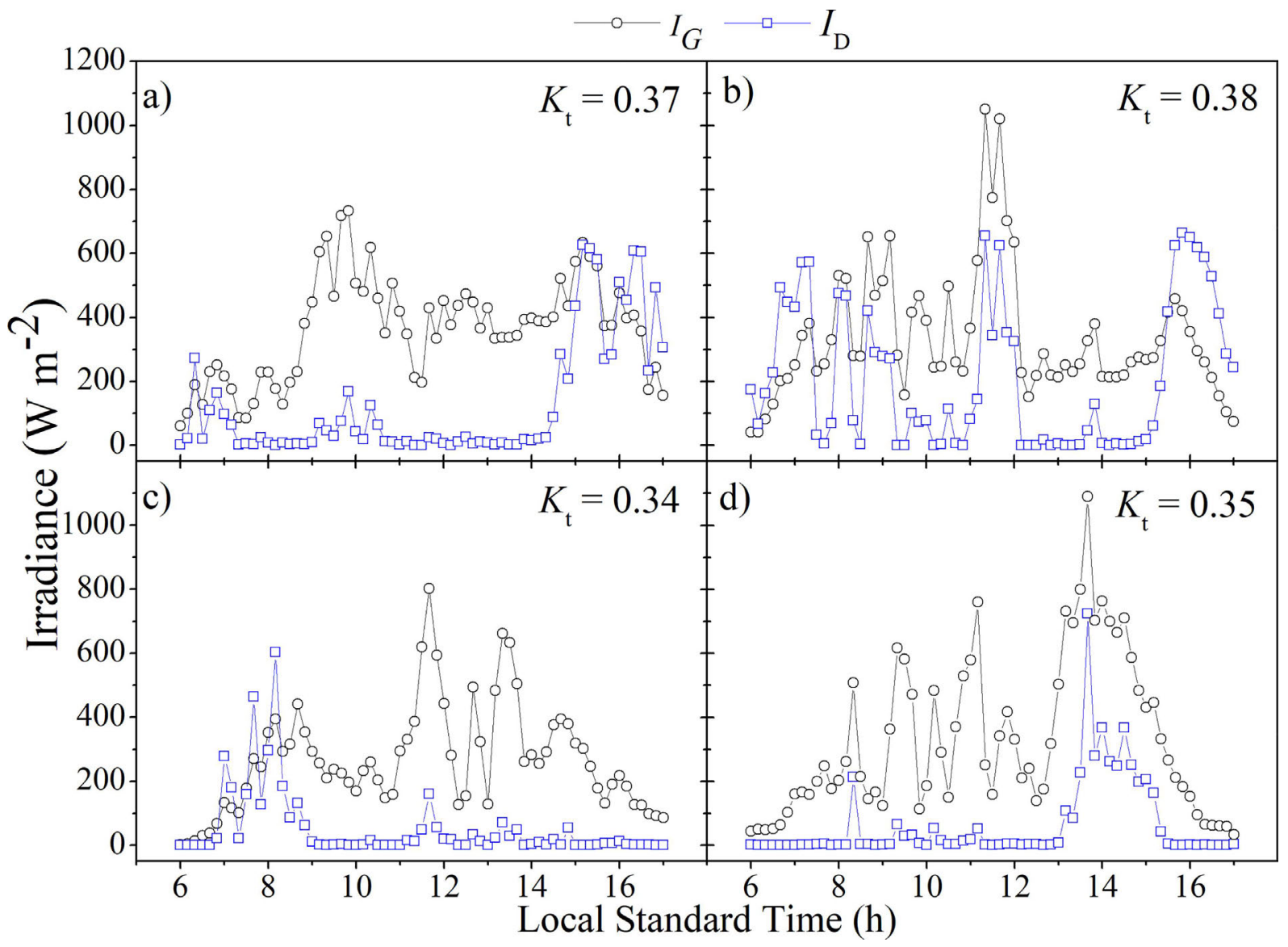

Figura 7 - Variation of global $\left(I_{G}\right)$ and direct normal $\left(I_{D}\right)$ solar irradiances under overcast sky condition: (a) (12/30/2012) in dry season, (b) $(04 / 07 / 2014)$ in pre-rainy season, (c) $(08 / 05 / 2013)$ in rainy season and (d) $(10 / 01 / 2012)$ in pre-dry season. 
In PRS, the average daily $I_{G}$ and $I_{D}$ values were equal to $335.5 \pm 200.3 \mathrm{~W} \mathrm{~m}^{-2}$ and $208.3 \pm 226.6 \mathrm{~W} \mathrm{~m}^{-2}$, respectively (Fig. 7b). The daily $H_{G}$ and $H_{D}$ totals were equal to 13.46 and $8.24 \mathrm{MJ} \mathrm{m}^{-2}$, respectively. In RS, $I_{D}$ had values close to zero during the daytime period, the daily averages were $I_{G}=265.0 \pm 166.6 \mathrm{~W} \mathrm{~m}^{-2}\left(H_{G}{ }^{d}=\right.$ $\left.10.47 \mathrm{MJ} \mathrm{m}^{-2}\right)$ and $I_{D}=49.6 \pm 107.5 \mathrm{~W} \mathrm{~m}^{-2}\left(H_{D}{ }^{d}=1.94\right.$ MJ $\mathrm{m}^{-2}$ ), with daily maximum values of $I_{G}=$ $801.9 \mathrm{~W} \mathrm{~m}^{-2}$ and $I_{D}=603.0 \mathrm{~W} \mathrm{~m}^{-2}$ (Fig. $7 \mathrm{c}$ ). The daily totals were the lowest, since the selected day belongs to the rainy season and has low $K_{t}$ value. In relation to OS days in RS (Souza et al., 2005; Porifírio et al., 2012) found similar values with measurements in the same location from different years. The average daily $I_{G}$ and $I_{D}$ values were $328.6 \pm 243.3 \mathrm{~W} \mathrm{~m}^{-2}\left(H_{G}{ }^{d}=13.18 \mathrm{MJ} \mathrm{m}^{-2}\right)$ and $61.2 \pm 126.3 \mathrm{~W} \mathrm{~m}^{-2}\left(H_{D}{ }^{d}=2.38 \mathrm{MJ} \mathrm{m}^{-2}\right)$ and daily peaks reached $1089.5 \mathrm{~W} \mathrm{~m}^{-2}$ and $723.7 \mathrm{~W} \mathrm{~m}^{-2}$, respectively (Fig. 7d). Study $I_{G}$ and $I_{D}$ Souza et al. (2005), Vilani et al. (2006) and Porifírio et al. (2012) found values with the same quantitative characteristics regarding the periods of greatest and smallest oscillations. The influence of cloudiness on $I_{G}$ and $I_{D}$ levels is remarkable. In addition, atmospheric water vapor has strong absorption in the region of the infrared spectrum, being able to reduce significantly the values of irradiances incident on the surface. The small differences observed along the analyzed periods show that energy totals are more affected by cloudiness than by seasonal variation, when compared with days of CS.

\subsection{Hourly average of the global $\left(\bar{I}_{G}^{h}\right)$ and direct normal $\left(\bar{I}_{D}^{h}\right)$ solar irradiance}

In DS under CS condition, the maximum $\bar{I}_{G}^{h}$ value was $765.6 \pm 100.0 \mathrm{~W} \mathrm{~m}^{-2}$ occurred between 09:00 am and 12:00 pm and was $728.2 \pm 29.9 \mathrm{~W} \mathrm{~m}^{-2}(12: 00 \mathrm{pm}-03: 00$ $\mathrm{pm}$ ), which were the highest values found for CS (Table 1). Under PCS condition, the maximum $\bar{I}_{G}^{h}$ and $\bar{I}_{D}^{h}$ values were $608.6 \pm 91.6 \mathrm{~W} \mathrm{~m}^{-2}$ and $420.5 \pm$ $26.8 \mathrm{~W} \mathrm{~m}^{-2}$, respectively. Under OS condition, $\bar{I}_{G}^{h}$ had maximum value of $354.9 \pm 49.2 \mathrm{~W} \mathrm{~m}^{-2}$ and $\bar{I}_{D}^{h}$ with maximum value of $197.3 \pm 16.7 \mathrm{~W} \mathrm{~m}^{-2}$. The lowest values are found for OS condition and the highest values for the CS condition, evidencing the effect of clouds and atmospheric constituents on the attenuation of irradiances.

In PRS under CS condition, the maximum $\bar{I}_{G}^{h}$ and $\bar{I}_{D}^{h}$ values were $829.3 \pm 105.0 \mathrm{~W} \mathrm{~m}^{-2}$ and $739.9 \pm 31.8 \mathrm{~W}$ $\mathrm{m}^{-2}$, which represents an increase of 8.31 and $1.59 \%$, when compared to DS values (Table 2). For the PCS condition, the highest global and direct irradiance values were $674.2 \pm 97.8 \mathrm{~W} \mathrm{~m}^{-2}$ and $425.2 \pm 18.9 \mathrm{~W} \mathrm{~m}^{-2}$, respectively, indicating an increase of $10.76 \%$ in $\bar{I}_{G}^{h}$ and $1.10 \%$ the $\bar{I}_{D}^{h}$ in relation to ES. Under OS condition, the maximum $\bar{I}_{G}^{h}$ and $\bar{I}_{D}^{h}$ values were $367.2 \pm 40.2 \mathrm{~W} \mathrm{~m}^{-2}$ and $196.1 \pm 3.6 \mathrm{~W} \mathrm{~m}^{-2}$, respectively, an increase of $6.47 \%$ and decrease of $0.60 \%$ in comparison to DS. The lowest $\bar{I}_{D}^{h}$ values are observed in PRS under OS condition. As RS is prolonged, there is a relatively higher presence of clouds, increased humidity and absorption of near infrared (NIR) radiation of the solar spectrum, which produces low $\bar{I}_{D}^{h}$ magnitude.

Under CS condition for RS, irradiances had maximum $\bar{I}_{G}^{h}$ values $=712.2 \pm 103.4 \mathrm{~W} \mathrm{~m}{ }^{-2}$ and $\bar{I}_{D}^{h}$ values $=$ $649.0 \pm 37.7 \mathrm{~W} \mathrm{~m}^{-2}$, reduction of $\approx 16.42 \%$ and $\approx 14 \%$ in relation to PRS, respectively (Table 3). Under PCS condition, the maximum $\bar{I}_{G}^{h}$ value was $572.6 \pm 65.7 \mathrm{~W} \mathrm{~m}^{-2}$ (decrease of $\approx 17.73 \%$ ) and $\bar{I}_{D}^{h}$ was $347.7 \pm 10.5 \mathrm{~W} \mathrm{~m}^{-2}$ (reduction of $\approx 22.28 \%$ ) compared to PRS. Under OS condition, $\bar{I}_{G}^{h}$ has maximum value of $354.0 \pm 45.6 \mathrm{~W} \mathrm{~m}^{-2}$, representing a reduction of $\approx 3.74 \%$ when compared to PRS; $\bar{I}_{D}^{h}$ reached maximum value of $169.1 \pm 59.7 \mathrm{~W} \mathrm{~m}^{-2}$, with a decrease of $\approx 15.98 \%$ compared to PRS.

Table 1 - Hourly average of the global $\left(\bar{I}_{G}^{h}, \mathrm{~W} \mathrm{~m}{ }^{-2}\right)$ and direct normal $\left(\bar{I}_{D}^{h}, \mathrm{~W} \mathrm{~m}{ }^{-2}\right)$ solar irradiances under different cloud cover for the dry season (November-February) with the respective standard deviations $\left(\delta I_{G}^{h}\right.$ and $\left.\delta I_{D}^{h}\right)$.

\begin{tabular}{|c|c|c|c|c|}
\hline & \multicolumn{4}{|c|}{ local time $(\mathrm{h})$ interval } \\
\hline & 06:00-09:00 & 09:00-12:00 & $12: 00-15: 00$ & $15: 00-17: 00$ \\
\hline & \multicolumn{4}{|c|}{ solar irradiance $\left(\mathrm{W} \mathrm{m}^{-2}\right)$ under $K_{t} \geq 0.60$} \\
\hline $\bar{I}_{G}^{h} \pm \delta I_{G}^{h}$ & $352.8 \pm 143.1$ & $765.6 \pm 100.0$ & $732.8 \pm 125.7$ & $305.1 \pm 146.4$ \\
\hline \multirow{2}{*}{$\bar{I}_{D}^{h} \pm \delta I_{D}^{h}$} & $480.2 \pm 48.5$ & $644.2 \pm 60.3$ & $728.2 \pm 29.9$ & $469.4 \pm 147.1$ \\
\hline & \multicolumn{4}{|c|}{ solar irradiance $\left(\mathrm{W} \mathrm{m}^{-2}\right)$ under $0.40 \leq K_{t}<0.60$} \\
\hline $\bar{I}_{G}^{h} \pm \delta I_{G}^{h}$ & $296.5 \pm 145.8$ & $608.6 \pm 91.6$ & $588.57 \pm 86.7$ & $244.06 \pm 129.7$ \\
\hline \multirow[t]{2}{*}{$\bar{I}_{D}^{h} \pm \delta I_{D}^{h}$} & $278.2 \pm 34.73$ & $354.2 \pm 56.6$ & $420.51 \pm 26.8$ & $301.08 \pm 78.5$ \\
\hline & \multicolumn{4}{|c|}{ solar irradiance $\left(\mathrm{W} \mathrm{m}^{-2}\right)$ under $K_{t}<0.40$} \\
\hline $\bar{I}_{G}^{h} \pm \delta I_{G}^{h}$ & $164.0 \pm 70.6$ & $344.9 \pm 49.2$ & $316.28 \pm 15.8$ & $145.35 \pm 72.3$ \\
\hline $\bar{I}_{D}^{h} \pm \delta I_{D}^{h}$ & $197.3 \pm 16.7$ & $161.0 \pm 17.7$ & $159.44 \pm 23.8$ & $124.17 \pm 32.6$ \\
\hline
\end{tabular}


The maximum $\bar{I}_{G}^{h}$ and $\bar{I}_{D}^{h}$ values under CS condition for PDS were $887.8 \pm 103.7 \mathrm{~W} \mathrm{~m}^{-2}$ and $657.3 \pm 46.7$ $\mathrm{W} \mathrm{\textrm {m } ^ { - 2 }}$, respectively, increasing $\approx 24.64 \%$ and $\approx 1.27 \%$ when compared to RS (Table 4). Under PCS conditions, the maximum $\bar{I}_{G}^{h}$ and $\bar{I}_{D}^{h}$ values were $690.9 \pm 103.2$ $\mathrm{W} \mathrm{m}{ }^{-2}$ and $406.9 \pm 21.6 \mathrm{~W} \mathrm{~m}^{-2}$, increase of $20.66 \%$ and

Table 2 - Hourly average of the global $\left(\bar{I}_{G}^{h}, \mathrm{~W} \mathrm{~m}{ }^{-2}\right)$ and direct normal $\left(\bar{I}_{D}^{h}, \mathrm{~W} \mathrm{~m}{ }^{-2}\right)$ solar irradiances under different cloud cover for the pre-rainy season (March and April) with the respective standard deviations $\left(\delta I_{G}^{h}\right.$ and $\left.\delta I_{D}^{h}\right)$.

\begin{tabular}{|c|c|c|c|c|}
\hline & \multicolumn{4}{|c|}{ local time (h) interval } \\
\hline & 06:00-09:00 & 09:00-12:00 & 12:00-15:00 & 15:00-17:00 \\
\hline & \multicolumn{4}{|c|}{ solar irradiance $\left(\mathrm{W} \mathrm{m}^{-2}\right)$ under $K_{t} \geq 0.60$} \\
\hline $\bar{I}_{G}^{h} \pm \delta I_{G}^{h}$ & $336.0 \pm 195.8$ & $829.3 \pm 105.0$ & $796.8 \pm 130.9$ & $317.9 \pm 164.9$ \\
\hline \multirow[t]{2}{*}{$\bar{I}_{D}^{h} \pm \delta I_{D}^{h}$} & $407.1 \pm 116.1$ & $625.2 \pm 83.5$ & $739.9 \pm 31.8$ & $494.6 \pm 131.3$ \\
\hline & \multicolumn{4}{|c|}{ solar irradiance $\left(\mathrm{W} \mathrm{m}^{-2}\right)$ under $0.40 \leq K_{t}<0.60$} \\
\hline $\bar{I}_{G}^{h} \pm \delta I_{G}^{h}$ & $279.9 \pm 169.6$ & $674.2 \pm 97.8$ & $652.4 \pm 110.4$ & $253.6 \pm 131.3$ \\
\hline \multirow[t]{2}{*}{$\bar{I}_{D}^{h} \pm \delta I_{D}^{h}$} & $272.2 \pm 60.1$ & $365.4 \pm 70.3$ & $425.2 \pm 18.9$ & $311.4 \pm 74.1$ \\
\hline & \multicolumn{4}{|c|}{ solar irradiance $\left(\mathrm{W} \mathrm{m}^{-2}\right)$ under $K_{t}<0.40$} \\
\hline $\bar{I}_{G}^{h} \pm \delta I_{G}^{h}$ & $191.5 \pm 120.8$ & $367.4 \pm 40.2$ & $338.3 \pm 45.9$ & $138.7 \pm 77.2$ \\
\hline $\bar{I}_{D}^{h} \pm \delta I_{D}^{h}$ & $101.6 \pm 21.0$ & $95.2 \pm 23.6$ & $41.4 \pm 27.1$ & $196.1 \pm 3.6$ \\
\hline
\end{tabular}

Table 3 - Hourly average of the global $\left(\bar{I}_{G}^{h}, \mathrm{~W} \mathrm{~m}{ }^{-2}\right)$ and direct normal $\left(\bar{I}_{D}^{h}, \mathrm{~W} \mathrm{~m}{ }^{-2}\right)$ solar irradiances under different cloud cover for the rainy season (May-August) with the respective standard deviations $\left(\delta I_{G}^{h}\right.$ and $\left.\delta I_{D}^{h}\right)$.

\begin{tabular}{|c|c|c|c|c|}
\hline & \multicolumn{4}{|c|}{ local time (h) interval } \\
\hline & 06:00-09:00 & 09:00-12:00 & $12: 00-15: 00$ & $15: 00-17: 00$ \\
\hline & \multicolumn{4}{|c|}{ solar irradiance $\left(\mathrm{W} \mathrm{m}^{-2}\right)$ under $K_{t} \geq 0.60$} \\
\hline $\bar{I}_{G}^{h} \pm \delta I_{G}^{h}$ & $285.5 \pm 195.7$ & $712.2 \pm 103.4$ & $666.5 \pm 113.5$ & $252.6 \pm 146.9$ \\
\hline \multirow{2}{*}{$\bar{I}_{D}^{h} \pm \delta I_{D}^{h}$} & $423.3 \pm 181.4$ & $583.5 \pm 91.7$ & $649.0 \pm 37.7$ & $405.1 \pm 132.5$ \\
\hline & \multicolumn{4}{|c|}{ solar irradiance $\left(\mathrm{W} \mathrm{m}^{-2}\right)$ under $0.40 \leq K_{t}<0.60$} \\
\hline $\bar{I}_{G}^{h} \pm \delta I_{G}^{h}$ & $228.5 \pm 159.0$ & $572.6 \pm 65.7$ & $532.0 \pm 91.6$ & $187.4 \pm 112.0$ \\
\hline \multirow[t]{2}{*}{$\bar{I}_{D}^{h} \pm \delta I_{D}^{h}$} & $247.0 \pm 88.0$ & $321.9 \pm 20.7$ & $347.7 \pm 10.5$ & $227.5 \pm 54.5$ \\
\hline & \multicolumn{4}{|c|}{ solar irradiance $\left(\mathrm{W} \mathrm{m}^{-2}\right)$ under $K_{t}<0.40$} \\
\hline $\bar{I}_{G}^{h} \pm \delta I_{G}^{h}$ & $149.0 \pm 101.9$ & $354.0 \pm 45.6$ & $332.8 \pm 62.1$ & $114.3 \pm 71.5$ \\
\hline $\bar{I}_{D}^{h} \pm \delta I_{D}^{h}$ & $169.1 \pm 59.7$ & $113.7 \pm 16.5$ & $117.0 \pm 8.7$ & $103.2 \pm 67.7$ \\
\hline
\end{tabular}

Table 4 - Hourly average of the global $\left(\bar{I}_{G}^{h}, \mathrm{~W} \mathrm{~m}{ }^{-2}\right)$ and direct normal $\left(\bar{I}_{D}^{h}, \mathrm{~W} \mathrm{~m}^{-2}\right)$ solar irradiances under different cloud cover for the pre-dry season (September and October) with the respective standard deviations $\left(\delta I_{G}^{h}\right.$ and $\left.\delta I_{D}^{h}\right)$.

\begin{tabular}{|c|c|c|c|c|}
\hline & \multicolumn{4}{|c|}{ Local time (h) interval } \\
\hline & 06:00-09:00 & 09:00-12:00 & $12: 00-15: 00$ & $15: 00-17: 00$ \\
\hline & \multicolumn{4}{|c|}{ solar irradiance $\left(\mathrm{W} \mathrm{m}^{-2}\right)$ under $K_{t} \geq 0.60$} \\
\hline $\bar{I}_{G}^{h} \pm \delta I_{G}^{h}$ & $373.5 \pm 177.8$ & $887.8 \pm 103.7$ & $803.5 \pm 156.4$ & $279.3 \pm 180.5$ \\
\hline \multirow{2}{*}{$\bar{I}_{D}^{h} \pm \delta I_{D}^{h}$} & $370.2 \pm 101.1$ & $586.4 \pm 29.8$ & $657.3 \pm 46.7$ & $360.3 \pm 169.9$ \\
\hline & \multicolumn{4}{|c|}{ solar irradiance $\left(\mathrm{W} \mathrm{m}^{-2}\right)$ under $0.40 \leq K_{t}<0.60$} \\
\hline $\bar{I}_{G}^{h} \pm \delta I_{G}^{h}$ & $310.0 \pm 153.8$ & $690.9 \pm 103.2$ & $624.7 \pm 94.5$ & $226.7 \pm 136.7$ \\
\hline \multirow[t]{2}{*}{$\bar{I}_{D}^{h} \pm \delta I_{D}^{h}$} & $215.8 \pm 36.6$ & $372.0 \pm 61.0$ & $406.9 \pm 21.6$ & $278.7 \pm 132.1$ \\
\hline & \multicolumn{4}{|c|}{ solar irradiance $\left(\mathrm{W} \mathrm{m}^{-2}\right)$ under $K_{t}<0.40$} \\
\hline $\bar{I}_{G}^{h} \pm \delta I_{G}^{h}$ & $216.53 \pm 107.48$ & $414.18 \pm 8.24$ & $442.92 \pm 70.28$ & $163.8 \pm 103.1$ \\
\hline $\bar{I}_{D}^{h} \pm \delta I_{D}^{h}$ & $298.24 \pm 68.55$ & $394.40 \pm 114.82$ & $532.03 \pm 35.76$ & $381.4 \pm 97.6$ \\
\hline
\end{tabular}


$17.01 \%$ with respect to RS. Under OS condition, he maximum $\bar{I}_{G}^{h}$ and $\bar{I}_{D}^{h}$ values were $442.9 \pm 70.2 \mathrm{~W} \mathrm{~m}^{-2}$ and $532.0 \pm 35.8 \mathrm{~W} \mathrm{~m}^{-2}$, increase of $\approx 25.12 \%$ for $\bar{I}_{G}^{h}$ and $\approx$ $314.66 \%$ for $\bar{I}_{D}^{h}$.

\subsection{Hourly solar irradiation}

Figure 8 shows the average hourly global solar irradiation $\left(\bar{H}_{G}^{h}\right)$ observed for all four seasons (obtained through the average irradiation of each hour interval). The diurnal variation among the different seasons is the same, increasing from morning until reaching maximum near noon and then falling until the end of the afternoon. In relation to this behavior, the hourly values tend to spread symmetrically to the solar half day. The largest curve amplitude is in DS, followed by PDS, PRS and RS. This behavior evidences the solar declination effect among seasons, the amplitude decreases as the day of the year distances from the summer solstice. The diurnal evolution is characterized by the effect of the zenith angle, since $\bar{H}_{G}^{h}$ is measured in the horizontal plane. In DS, the total $H_{G}$ value in the day is $22.47 \mathrm{MJ} \mathrm{m}^{-2}$, and the morning and afternoon values were 12.01 and $10.47 \mathrm{MJ} \mathrm{m}^{-2}$, respectively. The diurnal evolution in PRS has a decrease in values when compared to DS, $H_{G}{ }^{d}$ was $20.45 \mathrm{MJ} \mathrm{m}^{-2}$, with maximum hourly value $\left(\bar{H}_{G}^{h}=2.90 \mathrm{MJ} \mathrm{m}^{-2}\right)$. In RS, the hourly averages and the daily total $\left(H_{G}{ }^{d}=15.45 \mathrm{MJ} \mathrm{m}^{-2}\right)$ had the greatest reduction, and the maximum value at this season $H_{G}{ }^{d}=20.45 \mathrm{MJ} \mathrm{m}^{-2}$ and maximum hourly $\bar{H}_{G}^{h}=2.91 \mathrm{MJ}$ $\mathrm{m}^{-2}$. Approximate $\bar{H}_{G}^{h}$ values were also found by researchers Souza et al. (2005), Marques Filho et al. (2016) and Tahir and Asim (2018). Although they are not located at the same latitude, the results of Maceió are similar to those obtained at sites in Nigeria by Osinowo et al. (2015), which found a uniform pattern in the distribution of $\bar{H}_{G}^{h}$ was $\bar{H}_{G}^{h}=2.24 \mathrm{MJ} \mathrm{m}^{-2}$. The diurnal evolution in PDS for

values, with peaks ranging from (15.01 to 12.01$) \mathrm{MJ} \mathrm{m}^{-2}$ and with results observed in Saudi Arabia (AlYahya and Irfan, 2016).

The daytime variation of $\bar{H}_{G}^{h}$ has a decrease after 08:00 am returning to increase soon after. This is due to the greater cloudiness in the morning, caused by the effect of local wind circulation (sea breezes), which are responsible for creating a zone of convergence near the coast (front breeze), contributing to the formation of cumulus clouds until near 01:00 pm, when it is verified the formation of an area of suppression of cumulus clouds related to the displacement of the zones of breeze subsidence and convergence (National Research Council, 1992; Silva, 2003). This effect is more intense in $H_{D}$ because this component is measured with the sensor directly pointed at the solar disk. In DS, $H_{D}$ has value of $17.20 \mathrm{MJ} \mathrm{m}^{-2}$ and maximum hourly average direct solar normal $\left(\bar{H}_{D}^{h}\right)$ value $=$ $2.00 \mathrm{MJ} \mathrm{m}^{-2}$ (Fig. 8b). In PRS, the $H_{D}$ values were higher than in DS, with $H_{D}=18.38 \mathrm{MJ} \mathrm{m}^{-2}$ and maximum $\bar{H}_{D}^{h}=$ $2.23 \mathrm{MJ} \mathrm{m}^{-2} . \bar{H}_{D}^{h}$ has the lowest values in $\mathrm{RS}$, with = $12.48 \mathrm{MJ} \mathrm{m}^{-2}$ and maximum peak $\bar{H}_{D}^{h}=1.46 \mathrm{MJ} \mathrm{m}^{-2}$. In PDS, $H_{D}$ was $14.88 \mathrm{MJ} \mathrm{m}^{-2}$ and maximum $\bar{H}_{D}^{h}=1.90 \mathrm{MJ}$ $\mathrm{m}^{-2}$. The seasonal variation in the $\bar{H}_{D}^{h}$ transmission is associated with sky cover conditions: large (small) $K_{t}$ values are related to large (small) values of the $\bar{H}_{D}^{h}$ transmission. The local results resemble those obtained for two sites in Cyprus by Pashiardis et al. (2017), who performed a statistical analysis of $H_{D}$ values, results found by Marques Filho et al. (2016) for Rio de Janeiro and for locations in Kenya (Kariuki and Sato, 2018), with values from satellite and two places of Morocco (Gairaa et al., 2017).

\subsection{Frequency distribution of daily direct normal solar irradiance $\left(I_{D}{ }^{d}\right)$ in the different sky cover conditions}

In the frequency distribution of $I_{D}{ }^{d}$ for CS condition in the four seasons, it was observed that the $I_{D}{ }^{d}$ values in
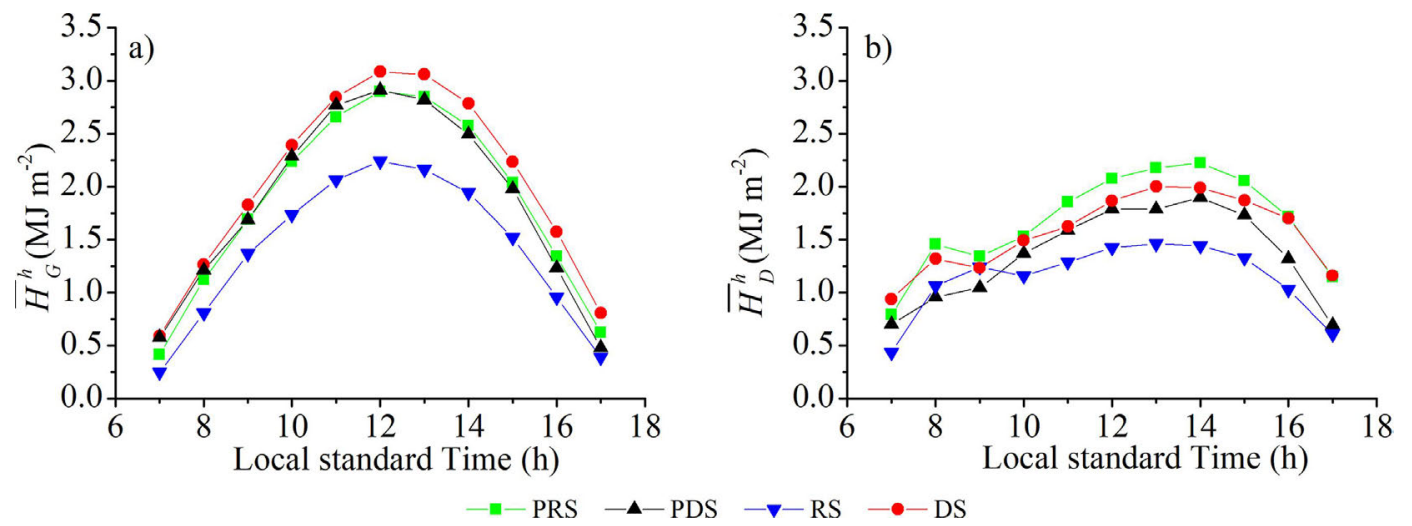

Figura 8 - The hourly average solar irradiation: a) global $\left(\bar{H}_{G}^{h}\right)$; b) direct solar normal $\left(\bar{H}_{D}^{h}\right)$. dry season (DS), pre-rainy season (PRS), rainy season (RS) and pre-dry season (PDS). 
DS had greater occurrence between 400 and $600 \mathrm{~W} \mathrm{~m}^{-2}$, comprising a relative occurrence rate of $68.8 \%$ of days, with higher occurrence of $I_{D}{ }^{d}$ for $440 \mathrm{~W} \mathrm{~m}^{-2}$ (Fig. 9a). Between 160 and $400 \mathrm{~W} \mathrm{~m}^{-2}, I_{D}{ }^{d}$ maintained at a relative occurrence rate of $13.6 \%$ and from $600 \mathrm{~W} \mathrm{~m}^{-2}$ up to the maximum value $\left(740 \mathrm{~W} \mathrm{~m}^{-2}\right)$, the relative occurrence rate corresponded to $17.6 \% . I_{D}{ }^{d}$ in PRS had relative occurrence rate of $65.91 \%$ between 400 and $600 \mathrm{~W} \mathrm{~m}^{-2}$, between 257.5 and $400 \mathrm{~W} \mathrm{~m}^{-2}$, the occurrence of $I_{D}{ }^{d}$ remained with relative occurrence rate of $15.69 \%$, but from 600 to $700 \mathrm{~W} \mathrm{~m}^{-2}$, the relative occurrence rate corresponded $18.19 \%$ of days (Fig. 9b). For RS, $I_{D}{ }^{d}$ had higher relative occurrence rate between 400 and $600 \mathrm{~W}$ $\mathrm{m}^{-2}$, which corresponds to about $60.92 \%$ of days of this season and from 252.5 to $400 \mathrm{~W} \mathrm{~m}^{-2}$, the occurrence reached $39.08 \%$ of cases (Fig. 9c). In PDS, $I_{D}{ }^{d}$ values between 385 and $635 \mathrm{~W} \mathrm{~m}^{-2}$ corresponded to half the relative occurrence rate of all values, the other half was between 235 and $385 \mathrm{~W} \mathrm{~m}^{-2}$ and the interval with the highest relative occurrence rate was between 385 and $435 \mathrm{~W} \mathrm{~m}^{-2}$, which totaled $27.77 \%$ (Fig. 9d). For the city of Daejeon, in South Korea, Lee et al. (2017) showed higher relative occurrence rate for $50 \mathrm{~W} \mathrm{~m}^{-2}$, followed by $850 \mathrm{~W} \mathrm{~m}^{-2}$ and with lower relative occurrence rate for $950 \mathrm{~W} \mathrm{~m}^{-2}$.
Under PCS condition, $I_{D}{ }^{d}$ for DS showed higher occurrence between 250 and $450 \mathrm{~W} \mathrm{~m}^{-2}$, totaling a relative occurrence rate of $55.43 \%$, from 10 to $250 \mathrm{~W} \mathrm{~m}^{-2}$, the relative occurrence rate was $41.30 \%$, in the interval from $450 \mathrm{~W} \mathrm{~m}^{-2}$ up to the maximum value $\left(I_{D}{ }^{d}=590 \mathrm{~W} \mathrm{~m}^{-2}\right)$, the relative occurrence rate was $3.27 \%$ (Fig. 10a). In PRS, $I_{D}{ }^{d}$ had relative occurrence rate of $60.47 \%$ for the interval from 200 to $400 \mathrm{~W} \mathrm{~m}^{-2}$ (Fig. 10b). From 60 to $200 \mathrm{~W}$ $\mathrm{m}^{-2}$, the percentage of $I_{D}{ }^{d}$ was $19.76 \%$ and from 400 to $600 \mathrm{~W} \mathrm{~m}^{-2}$, corresponding to relative occurrence rate of $19.77 \%$. The highest occurrence value of $I_{D}{ }^{d}$ was for the $300 \mathrm{~W} \mathrm{~m}^{-2}$. In the relative occurrence rate histograms of $I_{D}{ }^{d}$ for RS (Fig. 10c), higher occurrence was observed close to $230 \mathrm{~W} \mathrm{~m}^{-2}$, with higher relative occurrence rate $(80 \%)$ between 38 and $308 \mathrm{~W} \mathrm{~m}^{-2}$. In PDS, most occurrences of $I_{D}{ }^{d}$ were between 25 and $275 \mathrm{~W} \mathrm{~m}^{-2}$, totaling a relative occurrence rate of $70.83 \%$, between 275 and $675 \mathrm{~W} \mathrm{~m}^{-2}$ the relative occurrence rate of was $29.17 \%$ (Fig. 10d). In Seville - Spain, Moreno-Tejera et al. (2016) found that $42.4 \%$ of $I_{D}$ values $\mathrm{F}$ are higher than $600 \mathrm{~W}$ $\mathrm{m}^{-2}$, with higher relative occurrence rate of high values close to the summer solstice of the Southern Hemisphere.

Under OS condition, the behavior of $I_{D}{ }^{d}$ is different from the other sky covers, since the higher relative occurrence rate for values smaller than $100 \mathrm{~W} \mathrm{~m}^{-2}$ as observed

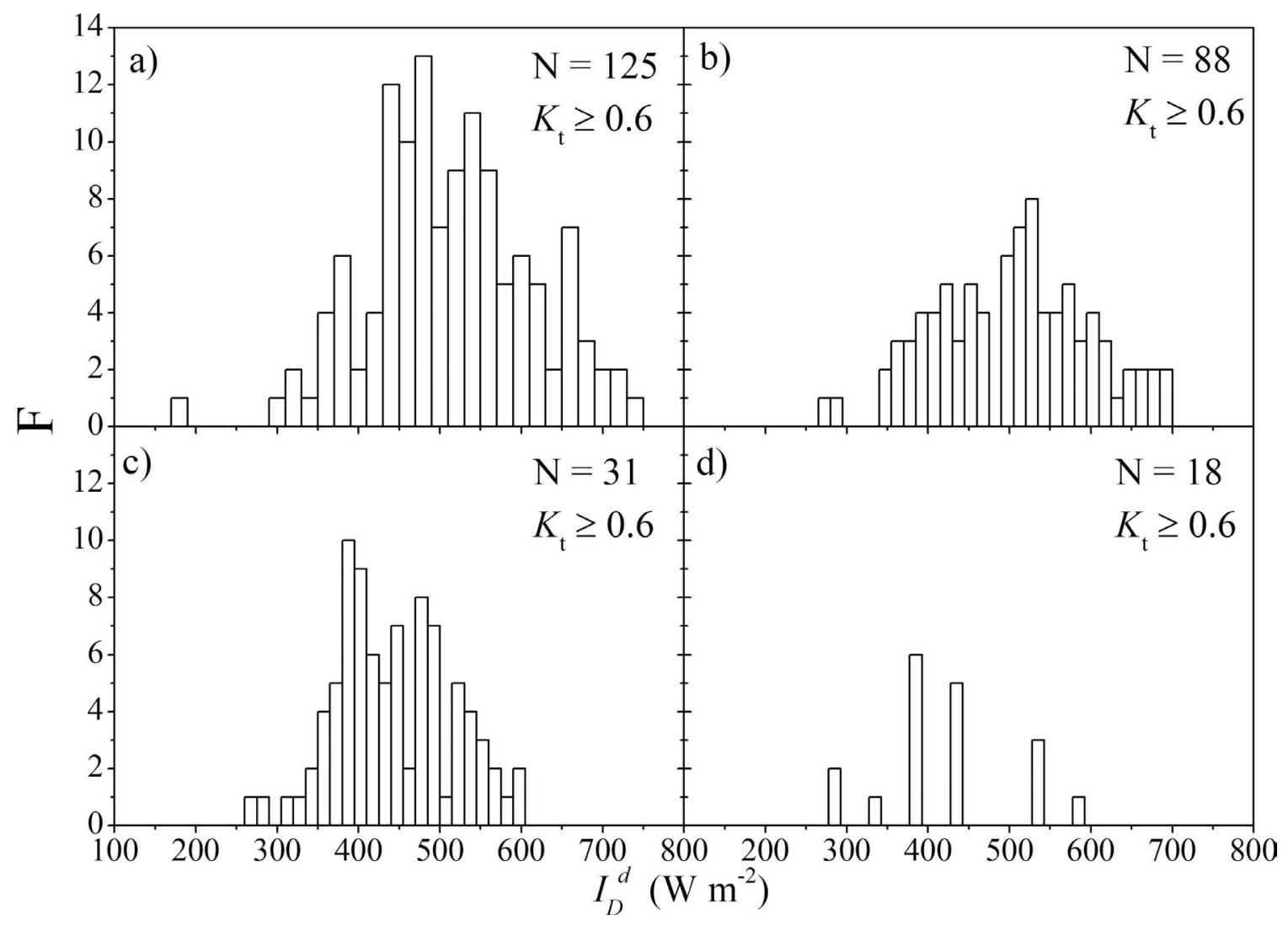

Figura 9 - Frequency distribution (F) of daily direct normal solar irradiance $\left(I_{D}{ }^{d}\right)$ under clear sky conditions: a) dry season; b) pre-rainy season; c) rainy season and d) pre-dry season. $\mathrm{N}=$ number of days. 


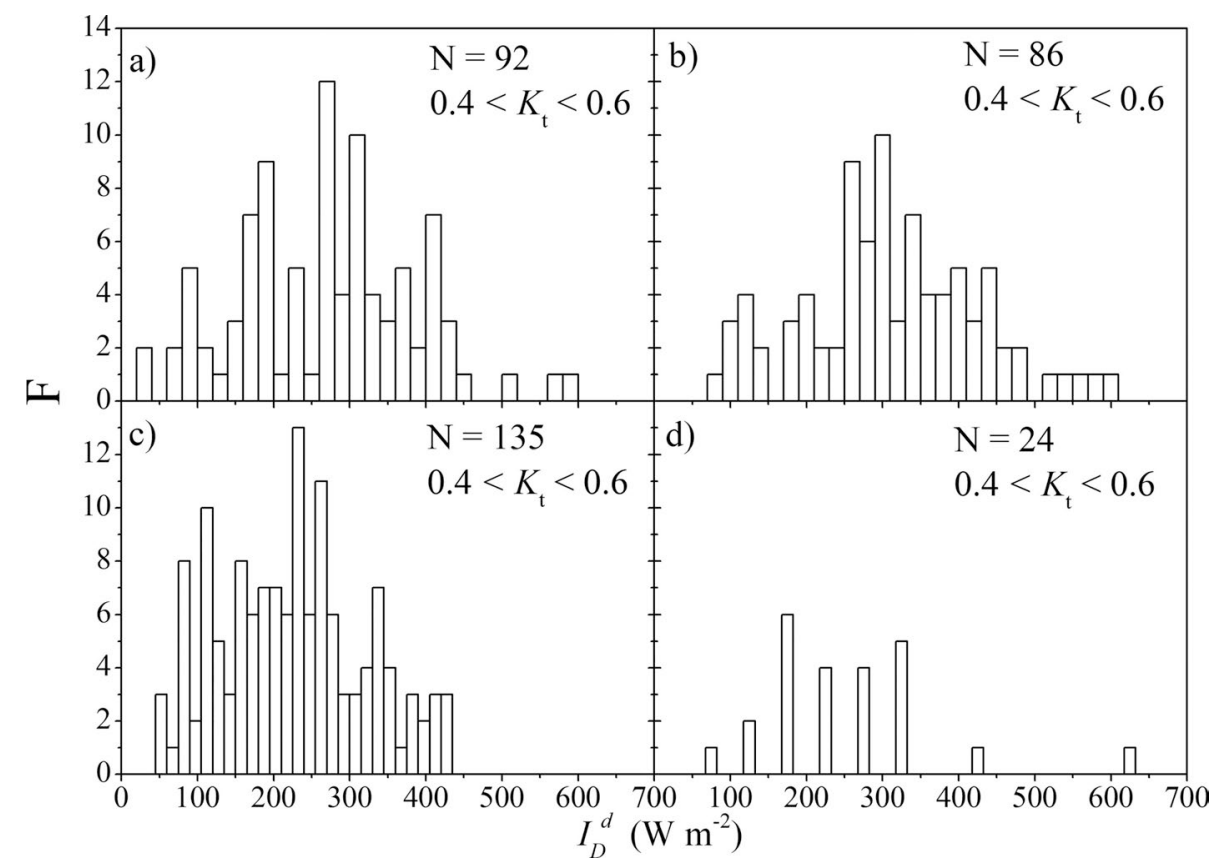

Figura 10 - Frequency distribution $(\mathrm{F})$ of daily direct normal solar irradiance $\left(I_{D}{ }^{d}\right)$ under partially cloudy sky conditions: a) dry season; b) pre-rainy season; c) rainy season and d) pre-dry season. $\mathrm{N}=$ number of days.

in DS (Fig. 11a), whose greatest occurrences were up to $188 \mathrm{~W} \mathrm{~m}^{-2}$, corresponding to a relative occurrence rate of $71.42 \%$ and in the interval from 188 to $563 \mathrm{~W} \mathrm{~m}^{-2}$, the corresponding relative occurrence rate is $28.58 \%$. For PRS, all $I_{D}{ }^{d}$ measurements were not higher than 200
$\mathrm{W} \mathrm{m} \mathrm{m}^{-2}$, with $55 \%$ of the relative occurrence rate up to $100 \mathrm{~W} \mathrm{~m}^{-2}$ (Fig. 11b). In RS, the maximum value was $155 \mathrm{~W} \mathrm{~m}^{-2}$, and up to $105 \mathrm{~W} \mathrm{~m}^{-2}$, the relative occurrence rate was $80.64 \%$ and from 105 to $155 \mathrm{~W} \mathrm{~m}^{-2}$, the relative occurrence rate was $19.36 \%$ (Fig. 11c). In PDS, the $I_{D}{ }^{d}$

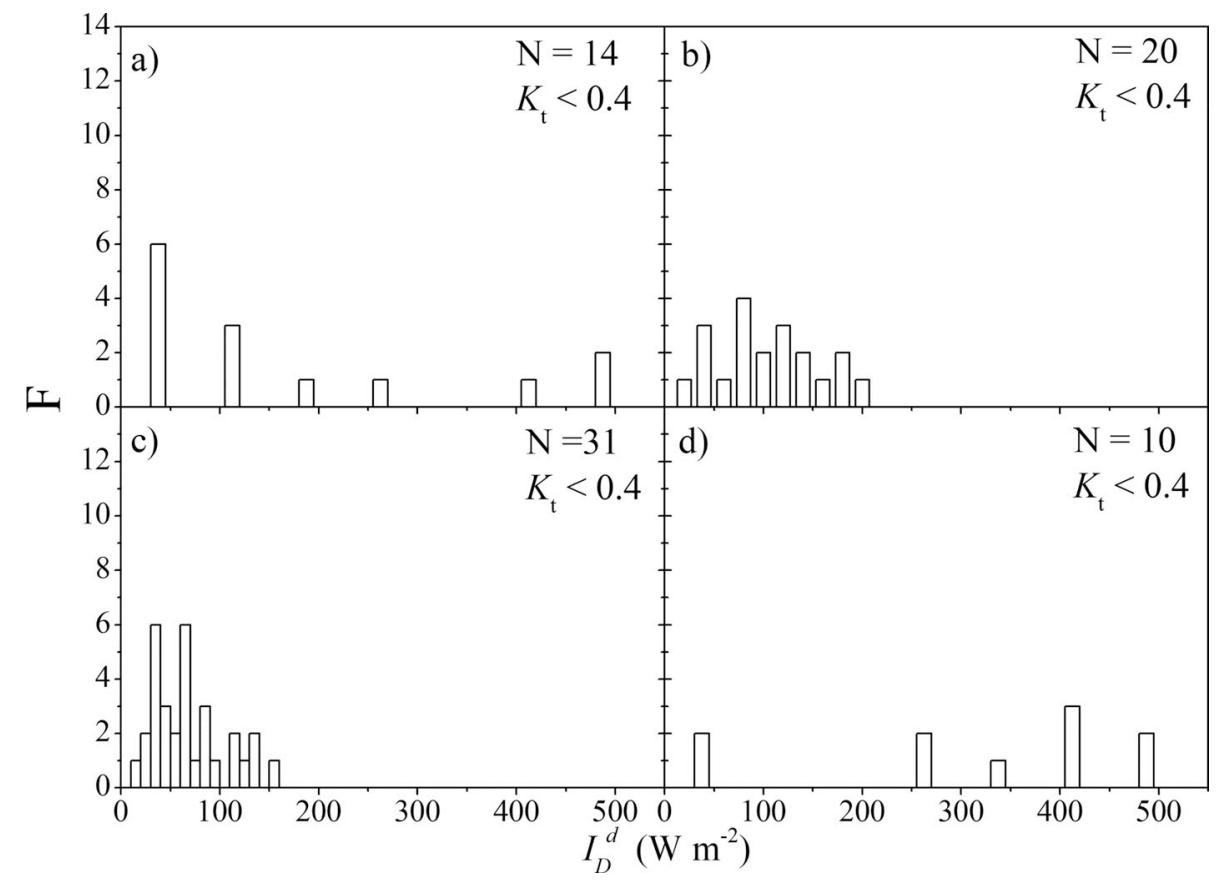

Figura 11 - frequency distribution $(\mathrm{F})$ of daily direct normal solar irradiance $\left(I_{D}{ }^{d}\right)$ under overcast sky conditions $\left(K_{t}<0.40\right)$ : a) dry season; b) pre-rainy season; c) rainy season and d) pre-dry season. $\mathrm{N}=$ number of days. 
values increased and the accumulated relative occurrence rate reached $100 \%$ up to a maximum of $488 \mathrm{~W} \mathrm{~m}^{-2}$ and $50 \%$ up to $338 \mathrm{~W} \mathrm{~m}^{-2}$ (Fig. 11d).

\section{Final considerations}

Cumulus clouds were mainly responsible for seasonal oscillation and irradiance attenuation, significantly reducing surface values. It was observed the phenomenon of multireflections that resulted in peaks and maximum values in the condition of partly cloudy days.

The instantaneous global and direct normal solar irradiance for seasonal periods showed maximum values close to noon, especially for clear sky conditions (global atmospheric transmittance, $K_{t} \geq 0.60$ ).

Higher oscillations were found in the intermediate seasonal periods (pre-rainy season - PRS and pre-dry season - PDS).

The daily totals of global and direct normal solar irradiation have greater variations due to the cloudiness than astronomical factors (seasonality), being the greatest values found, in the majority, in the morning during the dry and pre-rainy season.

The average daily totals of the global hourly solar irradiation were higher during the dry season, different from the direct totals that were higher in the pre-rainy season.

The lowest cloudiness levels were observed in the dry season, followed by pre-rainy, pre-dry and rainy seasons.

The relative occurrence rate of direct normal irradiance in the daily partition under conditions of $K_{t} \geq 0.60$ was greater between 400 and $700 \mathrm{~W} \mathrm{~m}^{-2}$. Under conditions of $0.4 \leq K_{t}<0.6, I_{D}{ }^{d}$ occurred more between 200 and $500 \mathrm{~W} \mathrm{~m}^{-2}$ and under conditions of $K_{t}<0.4$, it was below $200 \mathrm{~W} \mathrm{~m}^{-2}$.

Therefore, according to the obtained results, it could be inferred that the patterns of solar incidence in the region of study are dependent on the cloudiness conditions. On the other hand, seasonality is a secondary factor that has little influence on the configuration of energy patterns. Thus, it was possible to characterize the distribution of direct normal solar irradiance for the region of Maceió, but there is still a need to intensify these studies for better understanding and application in several human activities, notably engineering, energy, agriculture, health and environment.

\section{Acknowledgments}

The authors thank the Coordenação de Aperfeiçoamento de Pessoal de Nível Superior (CAPES), Conselho Nacional de Desenvolvimento Científico e Tecnológico (CNPq) and Centrais Elétricas Brasileiras S. A (Eletrobrás).

\section{References}

AlYahya, S.; Irfan, M.A. Analysis from the new solar radiation Atlas for Saudi Arabia. Solar Energy, v. 130, p. 116-127, 2016.

Andrade, R.C.; Tiba, C. Extreme global solar irradiance due to cloud enhancement in northeastern Brazil. Renewable Energy, v. 86, p. 1433-1441, 2016.

Barros, A.H.C.; Araujo Filho, J.C.; Silva, A.B.; Santiago, G.A.C.F. Climatologia do Estado de Alagoas. Recife: EMBRAPA SOLOS, 32p., 2012.

Cavaco, A.; Canhoto, P.; Costa, M.J.; Collares-Pereira, M. DNI measurements in the South of Portugal: Long term results through direct comparison with global and diffuse radiation measurements and existing time series. AIP Conference Proceedings 1734, 150001, 2016.

Chou, S.C. Análise de Distúrbios Ondulatórios de Leste Sobre o Oceano Atlântico Equatorial Sul. Dissertação de Mestrado em Meteorologia, Instituto Nacional de Pesquisas Espaciais, São José dos Campos, 134 p., 1990.

Chukwujindu, N.S.; Julie, O. Estimation of direct normal irradiance under various sky conditions in data sparse tropical ecological zones in Nigeria. Internacional Journal of Advanced Astronomy, v. 5, n. 2, p. 90-105, 2017.

Codato, G.; Oliveira, A.P.; Soares, J.; Escobedo, J.F.; Gomes, E.N.; Pai, A.D. D. Global and diffuse solar irradiances in urban and rural areas in southeast Brazil, Theor. Appl. Climatol., v. 93, p. 57-73, 2008.

Dugaria, S.; Padovan, A.; Sabatelli, V.; Del Col, D. Assessment of estimation methods of DNI resource in solar concentrating systems. Solar Energy, v. 121, p. 103-115, 2015.

Espinoza, E.S. Distúrbios nos Ventos de Leste no Atlântico Tropical. São José dos Campos: INPE, 149p., 1996.

Evseev, E.G.; Kudish, A.I. Analysis of solar irradiation measurements at Beer Sheva, Israel from 1985 through 2013. Energy Conversion and Management, v. 97, p. 307-314, 2015.

Ferreira Junior, R.A.; Souza, J.L.; Lyra, G.B.; Escobedo, J.F.; Santos, M.V.C. C. Energy conversion efficiency in sugarcane under two row spacings in northeast of Brazil. Revista Brasileira de Engenharia Agrícola e Ambiental, v. 19, n. 8, p. 741-747, 2015.

Gairaa, K.; Khellaf, A.; Benkacilai, S.; Guermoui, M. Solar radiation measurements in Algeria: case of Ghardaïa station as member of the enerMENA meteorological network. Energy Procedia, v. 141, p. 50-54, 2017.

Grantham, A.P; Pudney, P.J.; Ward, L.A.; Belusko, M.; Boland, J.W. Generating synthetic five-minute solar irradiance values from hourly observations. Solar Energy, v. 147, p. 209-221, 2017.

Gueymard, C.A. Temporal variability in direct and global irradiance at various time scales as affected by aerosols. Solar Energy, v. 86, p. 3544-3553, 2012.

Iqbal, M. An Introduction to Solar Radiation. New York: Academic Press, 390 p., 1983.

Kariuki, B.W.; Sato, T. Interannual and spatial variability of solar radiation energy potential in Kenya using Meteosat satellite. Renewable Energy, v. 116, Parte A, p. 88-96, 2018.

Kaskaoutis, D.G.; Kambezidis, H.D. The diffuse-to-global and diffuse-to-direct-beam spectral irradiance ratios as turbidity 
indexes in an urban environment. Journal of Atmospheric and Solar-Terrestrial Physics, v. 71, n. 2, p. 246-256, 2009.

Kotti, M.C.; Argiriou, A.A.; Kazantzidis, A. Estimation of direct normal irradiance from measured global and corrected diffuse horizontal irradiance. Energy, v. 70, n. 1, p. 382-392, 2014.

Kousky, V.E. Diurnal raifall variation on Northeast Brazil. Monthly Weather Review, v. 108, n. 4, p. 488-498, 1980.

Kousky, V.E. Frontal influences on Northeast Brazil. Monthly Weather Review, v. 107, n. 9, p. 1140-1153, 1979.

Lee, H-J.; Kim, S-Y.; Yun, C-Y. Comparison of Solar Radiation Models to Estimate Direct Normal Irradiance for Korea. Energies, v. 10, n. 5, p. 594, 2017.

Lima, M.C. Variabilidade da Precipitação no Litoral Leste da Região Nordeste do Brasil. Dissertação de Mestrado em Meteorologia, INPE - 5283 - TDI/453, 1991.

Liou, K.N. An Introduction to Atmospheric Radiation. 2. Ed. San Diego: Academic Press, 2002, 583p.

Liu, B.Y.H.; Jordan, R.C. The interrelationship and characteristic distribution of direct, diffuse and total solar radiation. Solar Energy, v. 4, n. 3, p. 1-19, 1960.

Lyra, G.B.; Oliveira Júnior, J.F.; Zeri, M. Cluster analysis applied to the spatial and temporal variability of monthly rainfall in Alagoas state, Northeast of Brazil. Internat Journ Climat, v. 34, n. 13, p. 3546-3558, 2014.

Marques Filho, E.P.; Oliveira, A.P.; Vita, W.A. et al. Global, diffuse and direct solar radiation at the surface in the city of Rio de Janeiro: Observational characterization and empirical modeling. Renewable Energy, v. 91, p. 64-74, 2016.

Molion, L.C.B.; Bernardo, S.O. Dinâmica das chuvas sobre o Nordeste do Brasil. In: Congresso Brasileiro de Meteorologia, 11, Rio de Janeiro, p. 1334-1342, 2000.

Molion, L.C.B.; Bernardo, S.O. Uma revisão da dinâmica das chuvas no nordeste brasileiro. Revista Brasileira de Meteorologia, v. 17, n. 1, p. 1-10, 2002.

Moreno-Tejera, S.; Silva-Perez, M.A.; Lillo-Bravo, I.; RamırezSantigosa, L. L. Solar resource assessment in Seville, Spain. Statistical characterisation of solar radiation at different time resolutions. Solar Energy, v. 132, p. 430-441, 2016.

Muneer, T. Solar Irradiation and Daylight Models. 2nd ed. Amsterdam: Elsevier, 2004.

National Research Council. 1992. Coastal Meteorology: A Review of the State of the Science. Washington: The National Academy Press, 1992. 112 p.

Oliveira, A.P.; Machado, J. A.; Escobedo, J. F.; Soares, J. Diurnal evolution of solar irradiation at the surface in the city of Sao Paulo: Seasonal variation and modeling, Theor. Appl. Climatol., v. 71, n. 3-4, p. 231-249, 2002.

Osinowo, A.A.; Okogbue, E.C.; Ogungbenro, S.B.; Fashanu, O. Analysis of Global Solar Irradiance over Climatic Zones in Nigeria for Solar Energy Applications. Journal of Solar Energy, Volume 2015, Article ID 819307, 9 p.

Pashiardis, S.; Kalogirou, S.A.; Pelengaris, A. Statistical analysis for the characterization of solar energy utilization and intercomparison of solar radiation at two sites in Cyprus. Applied Energy, v. 190, p. 1138-1158, 2017.
Podstawczynska, A. UV and global solar radiation in Lodz, central Poland. International Journal Climatology, v. 30, n. 1, p. 1-10, 2010.

Polo, J.; Fernández-Peruchena, C.; Gastón, M. Analysis on the long-term relationship between DNI and CSP yield production for different technologies. Solar Energy, v. 155, p. 1121-1129, 2017.

Porfírio, A.C.S.; Souza, J.L.; Lyra, G.B.; Lemes, M.A.M. An assessment of the global UV solar radiation under various sky conditions in Maceió-Northeastern Brazil. Energy, v. 4 4, n. 1, p. 584-592, 2012.

Reboita, M.S.; Krusche, N.; Ambrizzi, T.; Porfírio, R. Entendendo o tempo e o clima na América do Sul. Terrae Didatica, v. 8, n. 1, p.34-50, 2012.

Ruiz-Arias, J.A.; Gueymard, C.A.; Santos-Alamillos, F.J.; PozoVázquez, D. D. Worldwide impact of aerosol's time scale on the predicted long-term concentrating solar power potential. Scientific Reports, 6, 30546, 2016.

Santos, C.M.; Escobedo, J.F.; Teramoto, E.T.; Silva, S.H.M.G. Assessment of ANN and SVM models for estimating normal direct irradiation $\left(H_{b}\right)$. Energy Conversion and Management, v. 126, p. 826-836, 2016.

Santos, C.M.; Souza, J.L.; Ferreira Junior, R.A.; Tiba, C.; Melo, R.O. et al. On modeling global solar irradiation using air temperature for Alagoas State, Northeastern Brazil. Energy, v. 71, p. 388-398, 2014.

Silva, G.R. Características de Vento na Região Nordeste: Análise, Modelagem, e Aplicações Para Projetos de Centrais Eólicas. Dissertação de Mestrado em Engenharia Mecânica, Universidade Federal de Pernambuco, Recife, 141 p., 2003.

Souza, J.L.; Moura Filho, G.; Fonseca, R.F.; Teodoro, I.; Santos, E.A. et al. Análise da precipitação pluvial e temperatura do ar na região do Tabuleiro Costeiro de Maceió, AL, período 1972 - 2001. Revista Brasileira de Agrometeorologia, v. 11, n. 2, p.131-141, 2004.

Souza, J.L.; Lima, F.Z. Clima - Estudo de Impactos Ambiental, Levantamento Ambiental e Relatório, no Meio Ambiente de Área de Proteção Ambiental de Piaçabuçu - AL. In: Relatório Técnico, Maceió: UFAL, p. 180-238, 1995.

Souza, J.L.; Nicácio, R.M.; Moura, M.A.L. Global solar radiation measurements in Maceió, Brazil. Renewable Energy, v. 30, n. 8, p. 1203-1220, 2005.

Tabari, H.; Talaee, P.H. Sensitivity of evapotranspiration to climatic change in different climates. Glob. Planet. Chang., v. 115, p. 16-23, 2014.

Tahir, Z.R.; Asim, M. Surface measured solar radiation data and solar energy resource assessment of Pakistan: A review. Renewable and Sustainable Energy Reviews, v. 81, Parte 2, p. 2839-2861, 2018.

Tiba, C. Solar radiation in the Brazilian Northeast. Renewable Energy, v. 22, p. 565-578, 2001.

Vick, B.D.; Daryl, R.; Myers, D.R.; Boyson, W.E. Using direct normal irradiance models and utility electrical loading to assess benefit of a concentrating solar power plant. Solar Energy, v. 86, n. 12, p. 3519-3530, 2012.

Vilani, M.T.; Sanches, L.; Nogueiram, J.S.; Priante Filho, N. Sazonalidade da radiação, temperatura, e umidade em uma 
floresta de transição Amazônia Cerrado. Revista Brasileira de Meteorologia.v. 21, n. 3b, p. 331-343, 2006.

WMO. Guide to Meteorological Instruments and Methods of Observation. WMO-n ${ }^{\circ}$, Seventh Edition, 157-197, Geneva, Switzerland, 2008.

\section{Internet Resources}

http://www.soda-pro.com/home

\section{Nomenclature}

$I_{G}$ : global solar irradiance, $\mathrm{W} \mathrm{m}^{-2}$

$I_{D}$ : direct normal solar irradiance, $\mathrm{W} \mathrm{m}^{-2}$

$I_{d}$ : diffuse solar irradiance, $\mathrm{W} \mathrm{m}^{-2}$

$I_{0}$ : irradiance at the top of the atmosphere, $\mathrm{W} \mathrm{m}^{-2}$

$H_{G}$ : global solar irradiation, $\mathrm{MJ} \mathrm{m}^{-2}$

$H_{D}$ : direct normal solar irradiation, $\mathrm{MJ} \mathrm{m}^{-2}$

$H_{0}$ : irradiation at the top of the atmosphere, $\mathrm{MJ} \mathrm{m}^{-2}$

$K_{t}$ : clearness index, adimensional

$\bar{I}_{G}^{h}$ : average hourly of global solar irradiance, $\mathrm{W} \mathrm{m}^{-2}$

$\delta I_{G}^{h}$ : standard deviations of $I_{G}{ }^{h}, \mathrm{~W} \mathrm{~m}^{-2}$

$\bar{I}_{D}^{h}$ : average hourly of direct normal solar irradiance, $\mathrm{W}$ $\mathrm{m}^{-2}$

$\delta I_{D}^{h}$ : standard deviations of $\bar{I}_{D}^{h}, \mathrm{~W} \mathrm{~m}^{-2}$

$I_{S C}$ : solar constant, $1367 \mathrm{~W} \mathrm{~m}^{-2}$
$E_{0}$ : correction factor of the eccentricity of the Earth's orbit $\theta_{z}$ : zenith angle

NEB: Northeastern Brazil

ITCZ: Intertropical Convergence Zone

ULCV: Upper-Level Cyclonic Vortexes

EW: Eastern Waves

SACZ: South Atlantic Convergence Zone

SD: sunshine duration

DS: Dry Season

PRS: Pre-Rainy Season

RS: Rainy Season

PDS: Pre-Dry Season

CS: Clear Sky

PCS: Partially Cloudy Sky

OS: Overcast Sky

Upper index

$h$ : Hourly

$d$ : Daily

License information: This is an open-access article distributed under the terms of the Creative Commons Attribution License (type CC-BY), which permits unrestricted use, distribution and reproduction in any medium, provided the original article is properly cited. 